\title{
Impact of Natural Hazards on Agricultural Economy and Food Production in China: Based on a General Equilibrium Analysis
}

\author{
Shuai Zhong ${ }^{1}$, Mitsuru Okiyama ${ }^{2} \&$ Suminori Tokunaga ${ }^{1}$ \\ ${ }^{1}$ Graduate School of Life and Environmental Science, University of Tsukuba, Tsukuba, Ibaraki, Japan \\ ${ }^{2}$ GENDAI Advanced Studies Research Organization, Kudan-Minani, Chiyoda-ku, Tokyo, Japan \\ Correspondence: Shuai Zhong, 10-112 Hirasuna, 2-1-1 Amakubo, Tsukuba, Ibaraki 305-0005, Japan. Tel: \\ 81-080-3420-1928. E-mail: zhongshuai0714@gmail.com
}

Received: November 22, 2013 Accepted: February 27, 2014 Online Published: March 7, 2014

doi:10.5539/jsd.v7n2p45

URL: http://dx.doi.org/10.5539/jsd.v7n2p45

\begin{abstract}
Based on a standard general equilibrium model for China's macro economy with multi-regional sectors, including water, croplands, agricultural labor and rural households, this study estimated the impact on the agricultural economy and food production from natural hazards in 2007 and considered two simulations: i) the drought-exempt case, which supposed that a drought did not occur; ii) the flood-exempt case, which supposed that a flood did not occur. The discussion focuses on the results obtained from the drought-exempt case, which was similar to but more significant than the flood-exempt case, because the drought in 2007 was the most widespread in recent years and was also more serious than the flood. In both cases, real GDP obtained insignificant positive effects contributed by the rise of agricultural output, but the effects on nominal GDP was negative. All agricultural productions increased their outputs and exports, especially for sorghum, oil seed and corn. Another finding was that more capital and less labor were related to most crop productions. All food productions also increased their outputs and exports, thus their energy inputs increased, especially for sugar, meats and vegetables. Households benefited from lower prices for all agricultural and food products from more domestic outputs and fewer imports. However, more food consumption and higher welfare occurred in urban households rather than in rural households. This was due to the declines in the returns of cropland and in the wages of agricultural labor. The worst rural households were located in Shandong, Henan, Hebei, Yunnan, Anhui, and Heilongjiang.
\end{abstract}

Keywords: natural hazards, agricultural economy, food production, CGE model, multi-regional sectors

\section{Introduction}

In the past several decades, regional and paroxysmal meteorological disasters have dominated in many parts of China, causing great economic losses and affecting local sustainable development (Chen \& Yang, 2013). China's recent relentless droughts and floods have threatened millions of lives and agricultural production. Such impacts include the loss of US \$ 6 billion and the lack of water for 23 million people during the drought in the southwest in early 2010 and losses of US \$ 40 billion and 2, 000 deaths due to flooding in 2011 (Li, 2012). With respect to agriculture, unforeseen crop failures caused by natural hazards may also be instrumental in the reported losses. This paper uses a computable general equilibrium model with an energy module (CGE-Energy model) to quantify the effect of regional natural hazards (droughts and floods) on the agricultural economy and food production as well as their effects on regional rural households. 


\section{Background Literature Review and Hypothesis}

\subsection{Regions Affected by Natural Hazards}

\section{Drought and flood affected area unit: 1000 ha}

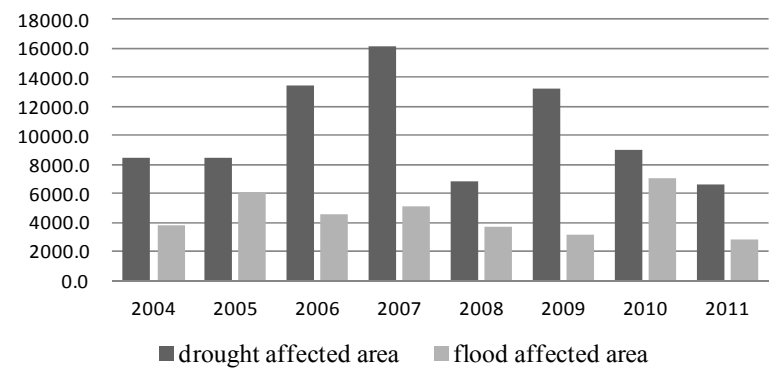

Figure 1. Changes in drought and flood affected areas from 2004 to 2011

Note: "Area" indicates cultivated area; "affected" means the cultivated area where yields are reduced by more than 30\% (Center for International Earth Science Information Network \& Socioeconomic Data and Applications Center [CIESIN \& SEDAC], 1997-2009). Data source: China Rural Statistics Yearbook 2012 (National Bureau of Statistics [NBSC], 2012).

In China, droughts have been widespread and have caused serious losses in throughout history while floods, on the other hand, are the most frequent natural disaster. According to Figure 1, droughts have affected larger areas than floods over these years. The most widespread drought occurred in 2007, where the nationally cultivated area affected by the drought was 16169.9 ha, an area that accounts for $10.54 \%$ of the total land area. The flood-affected area was 5104.7 ha in this same year, which was the third worst loss for 2007.
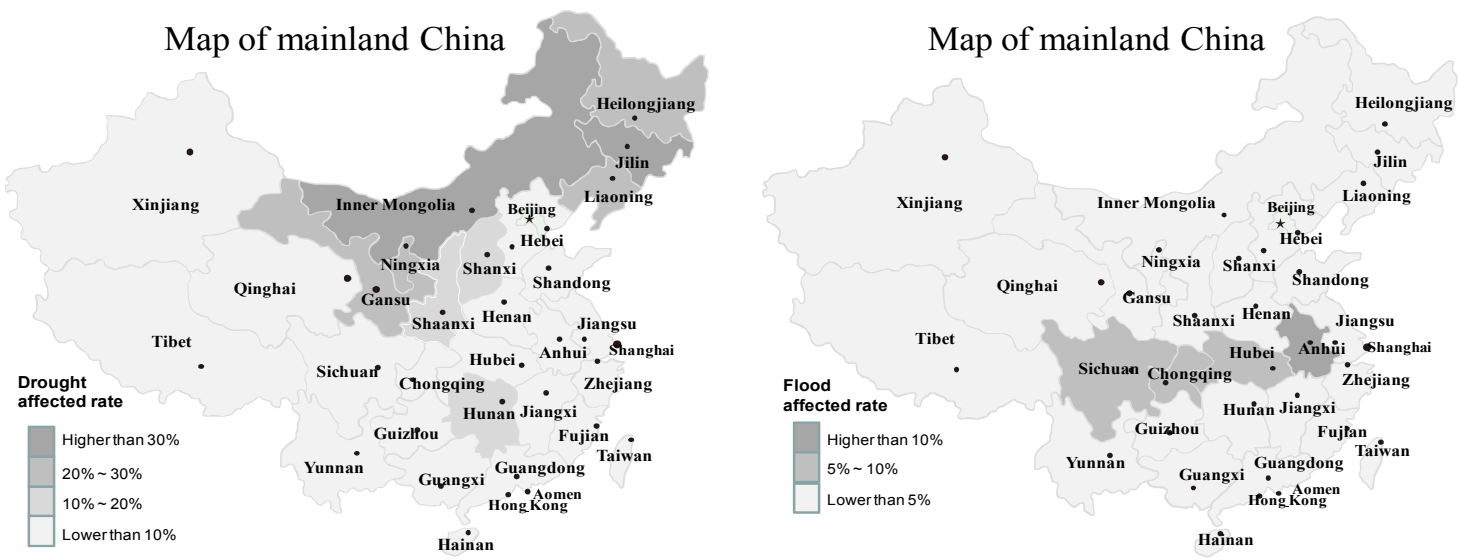

Figure 2. Regional drought and flood affected areas in 2007

Note: For each region, affected rate $=$ affected area / cultivated area. Data source: China Rural Statistics Yearbook 2012 (NBSC, 2012).

The distribution of the occurrence of natural disasters and their impact is a reflection of the regional disparities in physical geography as well as the social and economic development of China (Liu, Yang \& Li, 2012). With respect to the impact of natural disasters on regional development, the frequency of the disasters or the absolute loss in agriculture becomes the main consideration. Simelton (2011) contends that between 1955 and 2008, the southern parts of China experienced less severe drought impacts compared to the northern provinces, and the same or more intense flood impacts compared to the northern and southwestern provinces. The details of the regional areas affected by drought and flood of 2007 are displayed in Figure 2. As evidenced in this figure, the areas where the effects of the drought exceed 30\% include Inner Mongolia and Jilin, and those where the effects 
are between $20 \%$ and 30\% includes Liaoning, Heilongjiang, Gansu and Ningxia; Those areas hit hardest by the flood, that is, where the affected area exceeds $10 \%$ is Anhui, while the second most negatively impacted by the floods include the regions of Hubei, Chongqing and Sichuan.

\subsection{Food Consumption and Energy Requirement}

The size of China and its number of inhabitants --- one-fifth of the world's population --- along with the fact China has less than $7 \%$ of the world's cultivated land must be considered in this study (Zhao et al., 2008). Subsequent scientific analyses have noted that, while China produces approximately one-fifth of the grain produced globally, it trades very little in the three main staple crops --- rice, wheat and maize. Hence, China is largely self-sufficient (Dawe, 2009). This basic characteristic reveals the fact that the loss of cropland due to droughts and floods will have a profound influence on food security in China for decades, if not centuries (Yang $\& \mathrm{Li}, 2000$ ). Accordingly, while the significance attached to the national strategy for cropland protection, especially with respect to natural hazards, should be further enhanced and iterated on a regular basis, the systematic analysis of the macro economy, including the diversity in multi-regional households, is rarely found in the literature.

On the other hand, Harvey and Pilgrim (2011) argue that during a recent debate, a primacy of claim over land use for the production of food was staked, though the demand for energy and materials, in particular the development of alternatives to counter the depletion of petro-chemical resources, was not addressed in this debate, a failure that could inevitably result in major economic and social disruption on a global scale. In addition, Lucas, Jones and Hines (2006) posit that industrialized farming systems require 50 (sometimes up to 100) times the energy input of traditional agricultural systems, and it is estimated that $95 \%$ of all food products require the use of oil. Therefore, enhanced and sustainable social welfare will depend on developing new forms of agricultural production of both energy and food, highlighting the significance of the sustainable intensification of global agriculture (Godfray et al., 2010).

\subsection{Hypotheses}

We aim to simulate the short-term effects of the China droughts and floods of 2007. Based on the estimation from existing data regarding the affected areas at the regional level, we consider two cases, respectively: simulation 1, suppose the droughts did not occur (S1: Drought-exempt case); simulation 2, suppose the floods did not occur (S2: Flood-exempt case). We contend that a more significant impact will be observed in the Drought-exempt case than in the Flood-exempt case as a basic hypothesis. The detailed hypotheses that guide our research in this study include:

Hypothesis 1 (H1): In both cases, as all of the outputs of agricultural products will increase, their exports will also increase and their imports will decrease. The growth of agricultural production will contribute to the increase in real GDP, although the nominal GDP will decrease due to the lower consumer price index.

Hypothesis 2 (H2): In both cases, as all food products will increase, their exports will also increase and imports will decrease. Furthermore, the energy input in the food industries will increase.

Hypothesis 3 (H3): Because the price of food will decrease, urban households will benefit from the higher level of food consumption and welfare, while rural households will not benefit because their incomes will be significantly decreased due to the lower returns on cropland.

\section{Methodology and Database}

\subsection{Previous CGE Models of Agriculture}

By relying on Social Accounting Matrix (SAM), computable general equilibrium (CGE) models aggregate industries and products at a high level (Palatnik \& Roson, 2012). We constructed a standard CGE model for China's agricultural economy (Zhong, Okiyama, \& Tokunaga, 2013), based on Akune, Okiyama and Tokunaga (2011), Hosoe, Gasawa and Hashimoto (2010) and Tokunaga, Resosudarmo, Wuryanto and Dung (2003). In this paper, we extend this standard CGE model by adding multi-regional water demand and supply as well as a module for the substitution effect on more energy-efficient capital in food and energy production, namely, the CGE-Energy model, which is based on the EcoMod Modeling School (2013) program. This model also refers to Okiyama and Tokunaga (2010), Ge and Tokunaga (2011) and Ge, Lei and Tokunaga (2014) as well as previous CGE models with energy and water including GTAP-E (Burniaux \& Truong, 2002) and GTAP-W (Calzadilla, Rehdanz \& Tol, 2011). The detailed mathematical functions of CGE-Energy model are shown in Appendix 1. 


\subsection{Modeling Framework}

The standard CGE model has often criticized as being insufficiently validated (Beckman, Hertel, \& Tyner, 2011). Thus, the CGE-Energy model applied herein modifies the production structure of the standard CGE model to more closely represent the ability of firms to substitute among alternative fuels as well as among labor, capital and energy for food and energy production by removing energy from intermediate input nest and incorporating into the value-added nest, thus resulting in the GTAP-E model. The advantage of CGE model with energy is that this formulation allows for: i) the substitution among the relevant fuels; ii) the substitution between energy and capital in the energy-capital composite nest; and iii) substitution between the energy-capital composite nest and other factors (Nijkamp, Wang, \& Kremers, 2005). We refer to the GTAP-W model by combining multi-regional water inputs of different crop productions with their multi-regional croplands, where these water inputs are also removed from intermediate input.

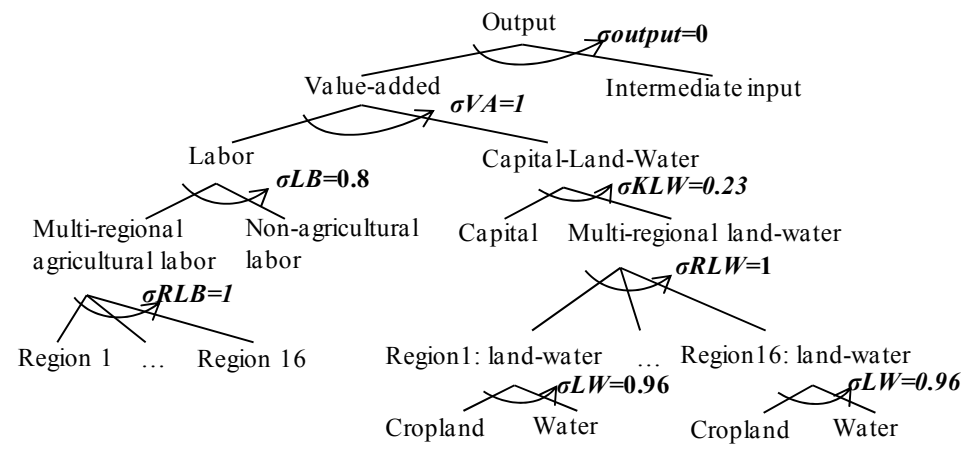

Figure 3. Nesting CES production structure of crop agricultural sectors

Note: $\sigma_{L B}=0.8$ and $\sigma_{R L B}=1$ are given from Ge and Tokunaga (2011); $\sigma_{K L W}=0.23$ and $\sigma_{L W}=0.96$ is from the GTAP-W model defined by Calzadilla et al (2011); $\sigma_{\text {output }}=0$ and $\sigma_{R L W}=1$ are related to Leontief and Cobb-Douglas assumptions respectively. Crop sectors include paddy, wheat, corn, vegetable, fruit, oil seed, sugarcane, potato, sorghum and other crops.

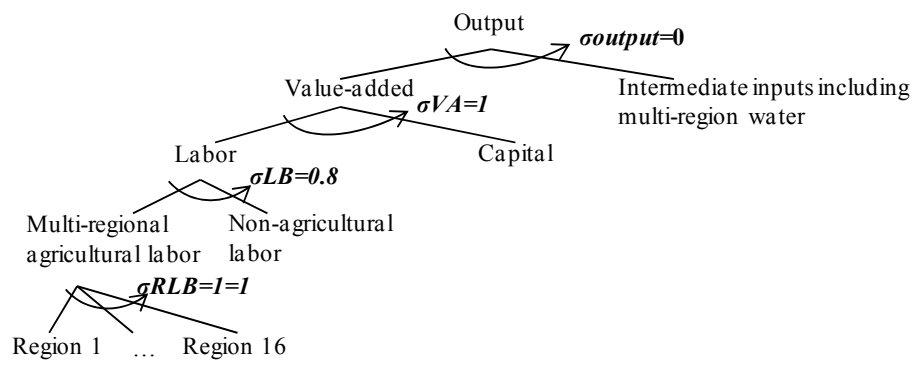

Figure 4. Nesting CES production structure of non-crop agricultural and construction sectors

Note: non-crop agricultural sectors include livestock, forestry, fishery and service for agriculture. 


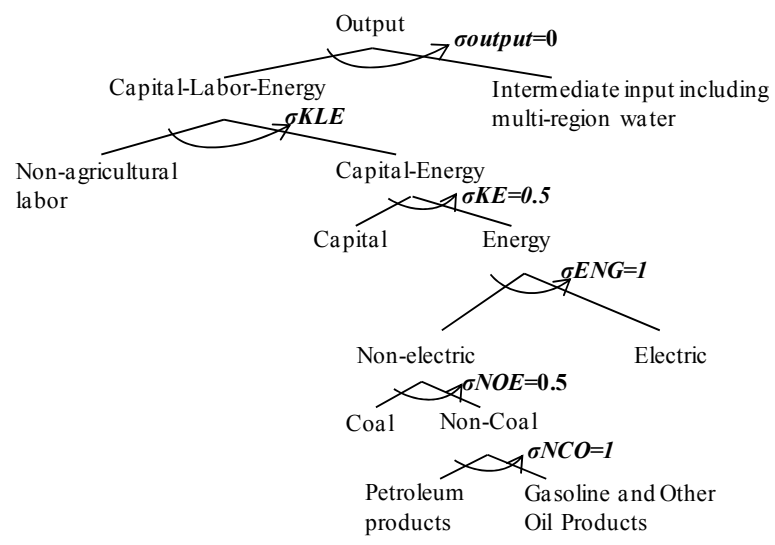

Figure 5. Nesting CES production structure of food and energy sectors

Note: the values of $\sigma_{K L E}, \sigma_{K E}, \sigma_{E N G}, \sigma_{N O E}$, and $\sigma_{N C O}$ refer to Burniaux and Truong (2002). Food sectors include meat, vegetable oil, milk, grain, sugar, other food and alcohol, drink and tobacco.

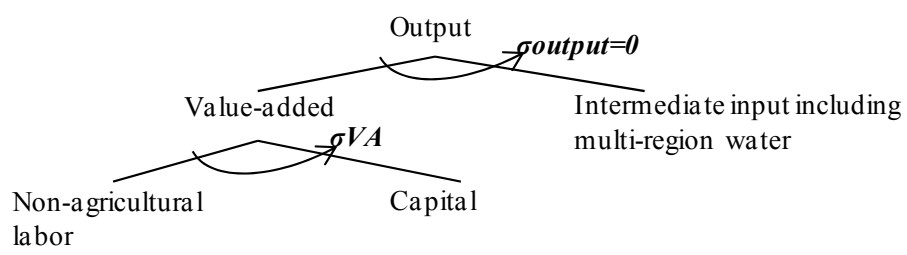

Figure 6. Nesting CES production structure of water and other sectors

Note: water sectors include 16 regional water productions, other mining, other manufactures, trade, transportation, insurance and finance, communication and computer and other service.

To minimize production costs, it is assumed that each sector produces one kind of good and that all sectors make production decisions in accordance with the principle of constant returns to scale. This model uses the nesting constant elasticity of substitution (CES) production function type. The nesting structures of the CES production function of different production sectors differ due to their differences of required input factors. We divide production sectors into three categories: i) the agriculture and construction sectors, which employ multi-regional inputs including croplands, waters, and agricultural labors combined with macro non-agricultural labor and capital; ii) the food and energy sectors, which require multi-energy inputs; and iii) the multi-regional waters as well as other sectors considered as normal in the standard CGE model. The nesting CES production structure of the above production sectors are shown in Figures 3-6. The values of substitution elasticity $(\sigma)$ are derived from previous studies.

\subsection{Database and Assumptions of Model}

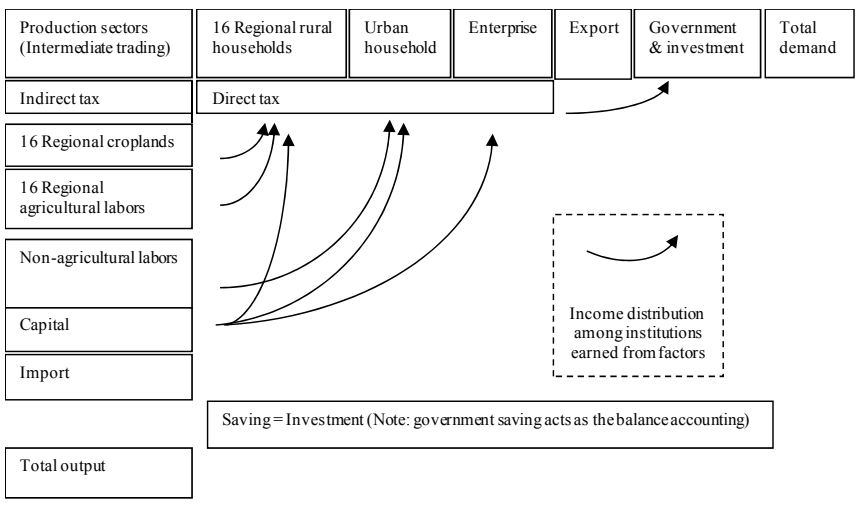

Figure 7. The CGE-Energy flows database 
The Social Accounting Matrix (SAM) applied in this CGE model is basically contributed by Ge and Tokunaga (2011) and Ge et al. (2014) (the simplified structure of SAM is displayed in Figure 7), and the detailed construction of SAM can be found in those studies. In short, the disaggregated information on regional inputs for sectoral cropland and agricultural labor is calculated by the data on area planting data from the China Agricultural Yearbook 2008 (NBSC, 2008a) and National Data Compilation of Revenue and Cost of Agricultural Products 2008 (NDRCC, 2008). The income distributions among government and enterprise as well as urban and rural households are derived from China Statistic Yearbook 2008 (NBSC, 2008b). Indeed, the SAM given from Ge and Tokunaga (2011) has only the aggregated account defined as the electrical, gas and water account without a signal water account. However, there is no data in detail regarding regional water inputs distributed by different agricultural and food productions. To separate this account, we use a constant share to derive the water account and the new aggregated account of electric power and gas. Furthermore, the regional water sectors - the production and distribution of water defined in office database, are derived from the China Regional Input-Output Table (NBSC, 2011). Since there are only two sectors --- agricultural sector and food sector defined in this regional input-output table, we assume the constant shares of regional water inputs are used to separate the sectoral water inputs in agricultural and food productions. These regional water sectors represent the water demand and supply at the regional level. Cropland, agricultural labor and rural household are also divided into 16 regions including Guangdong, Jiangxi, Hainan, Yunnan, Guangxi, Henan, Jilin, Anhui, Heilongjiang, Hebei, Hubei, Chongqing, Sichuan, Inner Mongolia, Shandong, and other regions, which are the same as those in the water sector. For the sake of brevity, the detailed SAM can be obtained from the authors upon request.

As a single country, open economy, the CGE model assumes a small country context in which the world prices of imports and exports are exogenously fixed. The CGE-Energy model follows the Armington (1969) assumption as do most CGE models. The domestic production of each commodity is allocated between domestic and export markets through a constant elasticity of transformation (CET) function, and the domestic consumption of each commodity is presented by an Armington composite commodity combined with domestic products and importing products according to the CES function. Those values of elasticity in the above functions are also derived from previous studies by Zhai and Hertel (2005) and Willenbockel (2006). The impart tariff of each sector is estimated by Ge and Tokunaga (2011). Together with the estimated values of the substitution elasticities obtained from the literature, the equilibrium is calibrated based on the underlying dataset.

On the consumption side, the consumption behaviors of multi-regional rural households (16 provinces, the same as those for water, agricultural labor and land) and one urban household are defined by the Stone-Gary utility function with diversity in the income elasticities of commodities (see Appendix 2). One of the important parameters for calibration when using the Stone-Gary utility function is the Frisch parameter, which describes the relation between the price elasticity and the income elasticity for each commodity. The value of the Frisch parameter is equal to -3.5 for all households according to Zhao and Wang (2008). There are two monetary measures for the changes in welfare compared with the benchmark equilibrium and the proposed change. The first measure is the equivalent variation (EV), which measures the income change at current prices that would be equivalent to the proposed change in terms of its impact on utility. The second monetary measure is the compensating variation $(\mathrm{CV})$, which measures the income change that would be necessary to compensate the consumer for the price change that is induced by the proposed change (EcoMod Modeling School, 2013). As in a typical CGE analysis, we only discuss the change in EV such that: if EV is positive, the simulation increases welfare, and if it is negative, the simulation decreases welfare. In addition, government consumption and investment are assumed to be Cobb-Douglas with respect to all commodities.

As the CGE-Energy model is a static equilibrium model, we interpret the benchmark equilibrium as a representation of the national economy over a period of time. The domestic prices of imports and exports are in Chinese Yuan (RMB). For simplicity, in the base year, all prices are assumed to equal one. The wage of non-agricultural labor is exogenously fixed as the numeraire price index. Other fixed valuables include the sectoral stock changes as the balancing account; the total amount of agricultural labor supply in different regions and the non-agricultural labor supply; the capital endowments from enterprise as well as urban and multi-regional rural households; and transfers from the rest of world, enterprise and government to households at the regional level; and the balance of total export and total import (namely, foreign saving). 


\section{Simulation Results and Discussion}

\subsection{Simulation Design}

Table 1. Modified values of cultivated land input in social accounting matrix

\begin{tabular}{lccccccccccc}
\hline Unit: 10000 yuan & PDR & WHT & COR & VEG & FRU & OSD & SUR & POT & SOR & $\begin{array}{c}\text { OCR } \\
\text { Modified } \\
\text { rate }\end{array}$ \\
\hline Guangdong & 33290 & 8 & 1392 & 20112 & 1149 & 2444 & 2297 & 2378 & 3 & 100665 & -0.01836 \\
Jiangxi & 24910 & 90 & 161 & 8173 & 1755 & 4183 & 145 & 995 & 21 & 3898 & -0.03144 \\
Hainan & 1468 & 0 & 183 & 2790 & 688 & 256 & 194 & 594 & 0 & 5306 & -0.02784 \\
Yunnan & 9775 & 2921 & 9502 & 9002 & 562 & 2057 & 3994 & 4154 & 34 & 1053 & -0.03033 \\
Guangxi & 29993 & 31 & 5121 & 19920 & 1660 & 1197 & 14247 & 1541 & 33 & 9882 & -0.02251 \\
Henan & 6003 & 54122 & 27750 & 31144 & 8389 & 18215 & 41 & 2099 & 44 & 5268 & -0.01737 \\
Jilin & 6024 & 40 & 49481 & 4343 & 1426 & 1722 & 0 & 671 & 808 & 2865 & -0.11669 \\
Anhui & 12035 & 11237 & 3341 & 13255 & 4410 & 5769 & 73 & 1212 & 14 & 787 & -0.03299 \\
Heilongjiang & 21117 & 2410 & 44941 & 4383 & 2558 & 1303 & 0 & 1511 & 568 & 1847 & -0.0795 \\
Hebei & 827 & 26120 & 29120 & 18547 & 2633 & 3842 & 0 & 1889 & 315 & 3963 & -0.03817 \\
Hubei & 11666 & 5441 & 2433 & 5783 & 2381 & 7924 & 48 & 1602 & 38 & 817 & -0.04202 \\
Chongqing & 6387 & 537 & 1552 & 4097 & 528 & 634 & 38 & 4992 & 115 & 2338 & -0.03796 \\
Sichuan & 20052 & 5803 & 5504 & 45743 & 1282 & 6280 & 79 & 8149 & 470 & 4577 & -0.03282 \\
Inner Mongolia & 729 & 5258 & 26063 & 4493 & 1107 & 3824 & 0 & 4253 & 1304 & 7233 & -0.10408 \\
Shandong & 1313 & 22483 & 17591 & 41347 & 6720 & 6353 & 0 & 1747 & 93 & 12691 & -0.01161 \\
Other regions & 94563 & 51237 & 75458 & 111868 & 19403 & 23881 & 682 & 21267 & 2450 & 931 & -0.04051 \\
\hline
\end{tabular}

PDR - paddy; WHT - wheat; COR - corn; VEG - vegetable; FRU - fruit; OSD - oil seed; SUR - sugarcane; POT - potato; SOR - sorghum; OCR - other crops.

The changes caused by natural disasters in our simulation focus on the variations of the cultivated areas at the regional level. Because the cropland in the SAM, as estimated by Ge and Tokunaga (2011), is the initial cultivated level without any information about drought and flood, the first step for this study is to modify those values by reducing the parts affected by the droughts and floods in 2007. These modified values for all crops are displayed in Table 1 . We define modified rate using the following method: affected farming area $=$ cultivated area of farming - drought affected area $* 0.3$ - flood affected area $* 0.3$; affected rate $=($ affected farming area initial farming area) / initial farming area. The affected area is defined by the National Bureau of Statistics as a cultivated area with more than 30\% harvest loss (CIESIN \& SEDAC, 1997-2009).

In a second step, the above modified values of cultivated land are input into SAM as a baseline to estimate the parameters (see Table 2) for two simulations: S1 supposes drought did not occur, namely, Drought-exempt case; and S2 supposes flood did not occur, namely, Flood-exempt case. We then test the three hypotheses. For example, with respect to the Guangdong region, if the drought did not occur, the modified value of its total cultivated area should increase by $1.36 \%$. If the flood did not occur, this value should increase by $0.830 \%$. 
Table 2. Values of regional cultivated land and the estimation of parameters for two simulations

\begin{tabular}{|c|c|c|c|c|}
\hline \multirow[b]{3}{*}{16 Regions } & \multirow{2}{*}{\multicolumn{2}{|c|}{$\begin{array}{l}\text { The amount of regional cultivated land in } 2007 \\
\text { Unit: } 10 \text { thousand yuan }\end{array}$}} & \multirow{2}{*}{\multicolumn{2}{|c|}{$\begin{array}{c}\text { Simulation parameters } \\
\text { Unit: } \%\end{array}$}} \\
\hline & & & & \\
\hline & $\begin{array}{l}\text { (1) Initial values of } \\
\text { regional land }\end{array}$ & $\begin{array}{l}\text { (2) Modified values of } \\
\text { regional land }\end{array}$ & $\begin{array}{l}\text { (3) Drought-exempt } \\
\text { Case, S1 }\end{array}$ & $\begin{array}{l}\text { (4) Flood-exempt } \\
\text { Case, S2 }\end{array}$ \\
\hline Guangdong & 166800 & 163738 & 1.360 & 0.830 \\
\hline Jiangxi & 45771 & 44332 & 3.306 & 0.561 \\
\hline Hainan & 11808 & 11479 & 0.000 & 3.328 \\
\hline Yunnan & 44401 & 43054 & 2.203 & 1.478 \\
\hline Guangxi & 85552 & 83626 & 1.957 & 0.693 \\
\hline Henan & 155782 & 153076 & 0.682 & 1.203 \\
\hline Jilin & 76281 & 67380 & 19.408 & 0.173 \\
\hline Anhui & 53911 & 52132 & 0.023 & 3.779 \\
\hline Heilongjiang & 87602 & 80638 & 11.185 & 0.071 \\
\hline Hebei & 90719 & 87256 & 3.341 & 3.036 \\
\hline Hubei & 39807 & 38134 & 1.730 & 3.401 \\
\hline Chongqing & 22056 & 21219 & 1.857 & 2.895 \\
\hline Sichuan & 101262 & 97939 & 2.045 & 1.916 \\
\hline Inner Mongolia & 60569 & 54265 & 18.696 & 0.315 \\
\hline Shandong & 111635 & 110339 & 0.825 & 0.393 \\
\hline Others & 418703 & 401739 & 4.100 & 0.997 \\
\hline
\end{tabular}

Note: Column (1) presents the initial value of regional total amount of cultivated lands from Ge and Tokunaga (2011); Column (2) lists the modified values of them equal to the summation of regional input croplands shown in Table 2; Columns (3) and (4) are estimated parameters according to the database regarding 16 regional totally cultivated areas and the areas affected by drought and flood. All data are derived from China Rural Statistics Yearbook 2012 (NBSC, 2012).

4.2 Results and Hypothesis Testing

4.2.1 Impacts on Macro Economy and Agricultural Production

Table 3. Change in macro economy

\begin{tabular}{lcc}
\hline Unit: $\%$ & S1: Drought-exempt case & S2: Flood-exempt case \\
\hline Nominal GDP & -0.0124 & -0.0035 \\
Real GDP & 0.0005 & 0.0001 \\
Consumer price index & -0.0193 & -0.0056 \\
Capital return & -0.0027 & -0.0008 \\
Exchange rate & -0.0072 & -0.0020 \\
Total consumption of household & -0.0158 & -0.0045 \\
Total investment & -0.0017 & -0.0005 \\
Total Export & -0.0014 & -0.0005 \\
Total import & -0.0023 & -0.0008 \\
Total output of crops & 0.0228 & 0.0068 \\
\hline
\end{tabular}


Table 3 presents the results generated by the macroeconomic effects of the two cases. S1 obtains more significant changes in all results than S2, regardless of sector, thus suggesting that in 2007, the drought had more serious implications than did the flood in China. However, in reality, the change in the macro economy exhibited no significance in either of two cases. S1 increases real GDP by $0.0005 \%$, which is mainly contributed by the increase of $0.0228 \%$ in the output of crops. The nominal GDP, on the other hand, decreases basically due to the $0.0193 \%$ reduction in the consumer price index. Furthermore, all of the other indices including capital return, exchange rate, total consumption, total investment, total export and total import suffer negative effects. As the changes in results of S2 are similar to S1, they are not more remarkable than S1. Therefore, if the droughts or the floods did not occur, the macro economy would not be expected to increase significantly, even thought there would be an increase in crop production.

Table 4. Changes in agricultural products

\begin{tabular}{lcccccccc}
\hline & \multicolumn{3}{c}{ S1: Drought-exempt case } & \multicolumn{4}{c}{ S2: Flood-exempt case } \\
& Output & Price & Export & Import & Output & Price & Export & Import \\
\hline Paddy & 0.011 & -0.107 & 0.369 & -0.503 & 0.004 & -0.032 & 0.112 & -0.153 \\
wheat & 0.028 & -0.114 & 0.393 & -0.473 & 0.012 & -0.047 & 0.167 & -0.200 \\
Corn & 0.078 & -0.312 & 1.121 & -0.384 & 0.013 & -0.048 & 0.170 & -0.057 \\
Vegetable & 0.015 & -0.100 & 0.341 & -0.226 & 0.005 & -0.034 & 0.119 & -0.079 \\
Fruit & 0.018 & -0.048 & 0.162 & -0.099 & 0.006 & -0.016 & 0.054 & -0.033 \\
Oil seed & 0.251 & -0.040 & 0.628 & -0.059 & 0.092 & -0.014 & 0.230 & -0.023 \\
Sugarcane & 0.021 & -0.076 & & -0.152 & 0.007 & -0.027 & & -0.054 \\
Potato & 0.036 & -0.167 & 0.610 & -0.387 & 0.011 & -0.051 & 0.188 & -0.120 \\
Sorghum & 1.289 & -0.837 & 3.652 & -2.023 & 0.162 & -0.108 & 0.458 & -0.259 \\
Other crops & 0.011 & -0.052 & 0.172 & -0.103 & 0.003 & -0.015 & 0.050 & -0.030 \\
Livestock & 0.010 & -0.062 & 0.210 & -0.073 & 0.003 & -0.016 & 0.053 & -0.018 \\
Forestry & 0.024 & -0.035 & 0.159 & -0.070 & 0.007 & -0.010 & 0.045 & -0.020 \\
Fishery & 0.011 & -0.048 & 0.156 & -0.044 & 0.003 & -0.013 & 0.043 & -0.012 \\
Service for Agriculture & 0.013 & -0.042 & 0.139 & -0.074 & 0.004 & -0.011 & 0.038 & -0.020
\end{tabular}

Note: "Price" is the price of Armington composite products aggregated from domestic and import products, and it presents the selling price the final demand including household should charge.

While all of the outputs and exports of crops are increased in S1 and S2, the results in S1 are more significant than S2. In S1, the best three crops are sorghum, oil seed and corn, which increase their outputs by $1.289 \%$, $0.251 \%$ and $0.078 \%$, respectively, and increase their exports by $3.652 \%, 0.628 \%$ and $1.121 \%$, respectively. S1 and S2 also decrease the price and import of all crops. Therefore, the domestic demand, for example, the household, will benefit from lower prices of agricultural products as the share of domestic products will increase (see Table 4). Therefore, according to the results presented in Tables 3 and 4, H1 is supported.

S1 also demonstrates more significant results than S2 in Table 5. Column ALW in S1 and S2 represents the simulation that if the drought or the flood did not occur, the croplands would increase, and thus, the aggregated regional cropland (ALW) would also increase. We also find that sorghum, potato and corn account for more of the ALW than the other crops, and their increase with respect to ALW are $5.730 \%, 1.721 \%$ and $3.332 \%$, respectively. A new finding is that most crop production requires greater capital and reduces the input of labor, including agricultural labor and non-agricultural labor. There are only two exceptions to this finding: sorghum and oil seed, which increase with respect to all of their inputs. Therefore, for these two cases, whereby more cropland is available, most crop productions employ more capital to substitute for labor and increase their outputs. Moreover, the released agricultural labor is reallocated into non-crop productions, such as livestock, forestry, fishery and service for agriculture. 
Table 5. Change in employment of crop productions

\begin{tabular}{lcccccccc}
\hline Unit: \% & \multicolumn{3}{c}{ S1: Drought-exempt case } & \multicolumn{3}{c}{ S2: Flood-exempt case } \\
& ALW & CAP & LAG & LNA & ALW & CAP & LAG & LNA \\
\hline Paddy & 0.980 & 0.549 & -0.125 & -0.173 & 0.302 & 0.170 & -0.039 & -0.052 \\
Wheat & 1.152 & 0.697 & -0.119 & -0.169 & 0.540 & 0.330 & -0.058 & -0.072 \\
Corn & 3.332 & 1.876 & -0.290 & -0.341 & 0.438 & 0.247 & -0.036 & -0.050 \\
Vegetable & 0.505 & 0.191 & -0.033 & -0.082 & 0.203 & 0.080 & -0.015 & -0.029 \\
Fruit & 0.686 & 0.124 & -0.042 & -0.091 & 0.245 & 0.046 & -0.017 & -0.031 \\
Oil seed & 1.287 & 0.636 & 0.146 & 0.098 & 0.506 & 0.250 & 0.049 & 0.035 \\
Sugarcane & 1.136 & 0.527 & -0.031 & -0.080 & 0.462 & 0.218 & -0.015 & -0.029 \\
Potato & 1.721 & 0.695 & -0.083 & -0.132 & 0.543 & 0.222 & -0.027 & -0.041 \\
Sorghum & 5.730 & 3.800 & 0.642 & 0.592 & 0.659 & 0.444 & 0.088 & 0.074 \\
Other crops & 0.607 & 0.436 & 0.007 & -0.042 & 0.216 & 0.156 & 0.002 & -0.012 \\
Livestock & & -0.044 & 0.014 & -0.034 & & -0.013 & 0.004 & -0.010 \\
Forestry & & -0.030 & 0.028 & -0.021 & & -0.008 & 0.008 & -0.006 \\
Fishery & & -0.042 & 0.015 & -0.033 & & -0.012 & 0.004 & -0.009 \\
Service for Agriculture & & -0.041 & 0.017 & -0.032 & & -0.012 & 0.005 & -0.009 \\
\hline
\end{tabular}

Note: ALW - Aggregated regional land and water; CAP - Capital; LAG - Aggregated regional agricultural labor; LNA - Non-agricultural labor.

4.2.2 Impacts on the Food Production

Table 6. Change in food products

\begin{tabular}{lllllllll}
\hline Unit: \% & \multicolumn{3}{c}{ S1: Drought-exempt case } & \multicolumn{4}{c}{ S2: Flood-exempt case } \\
& Output & Price & Export & Import & Output & Price & Export & Import \\
\hline Meat & 0.018 & -0.044 & 0.187 & -0.091 & 0.004 & -0.011 & 0.047 & -0.023 \\
Vegetable oils & 0.017 & -0.027 & 0.117 & -0.059 & 0.005 & -0.009 & 0.039 & -0.020 \\
Milk & 0.013 & -0.030 & 0.118 & -0.049 & 0.004 & -0.008 & 0.030 & -0.013 \\
Grain & 0.012 & -0.037 & 0.146 & -0.068 & 0.003 & -0.011 & 0.042 & -0.020 \\
Sugar & 0.022 & -0.038 & 0.175 & -0.075 & 0.007 & -0.013 & 0.059 & -0.026 \\
Other food & 0.021 & -0.031 & 0.122 & -0.045 & 0.006 & -0.009 & 0.035 & -0.013 \\
Alcohol, drinks and tobacco & 0.002 & -0.020 & 0.060 & -0.014 & 0.001 & -0.005 & 0.016 & -0.004 \\
\hline
\end{tabular}

Note: The meaning of this "Price" is the same in Table 4.

In both S1 and S2, as food productions increase their outputs and exports, the final products of food decrease in prices and imports (see Table 6). We focus on S1 where the increases in outputs of sugar, meat and vegetable are more significant than others with values of $0.022 \%, 0.018 \%$ and $0.017 \%$, respectively. However, the top three increases in exports are meat, sugar and grain at $0.187 \%, 0.175 \%$ and $0.146 \%$, respectively. Furthermore, meat, sugar and grain are consumed at slightly lower prices than other food products with declines in prices at $0.044 \%$, $0.038 \%$ and $0.037 \%$, respectively. Meat, sugar and grain are also the top three declining imports, reflecting lower import levels than other food products in that they decrease by $0.091 \%, 0.075 \%$ and $0.068 \%$, respectively. Accordingly, the demand for food products is met by more domestic products and fewer imports. 
Table 7. Change in energy input in food production

\begin{tabular}{|c|c|c|c|c|c|c|c|c|}
\hline Unit: \% & & MEP & VOL & MIL & GOG & SUG & OTF & ADT \\
\hline \multirow{8}{*}{ 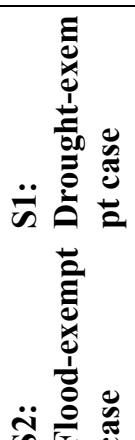 } & Coal & 0.021 & 0.019 & 0.015 & 0.015 & 0.024 & 0.023 & 0.004 \\
\hline & Petroleum & 0.021 & 0.020 & 0.016 & 0.015 & 0.024 & 0.024 & 0.005 \\
\hline & Gasoline & 0.021 & 0.020 & 0.016 & 0.015 & 0.024 & 0.024 & 0.005 \\
\hline & Electricity and gas & 0.020 & 0.019 & 0.015 & 0.014 & 0.023 & 0.023 & 0.004 \\
\hline & Coal & 0.005 & 0.006 & 0.004 & 0.004 & 0.008 & 0.007 & 0.001 \\
\hline & Petroleum & 0.006 & 0.006 & 0.004 & 0.004 & 0.008 & 0.007 & 0.001 \\
\hline & Gasoline & 0.006 & 0.006 & 0.004 & 0.004 & 0.008 & 0.007 & 0.001 \\
\hline & Electricity and gas & 0.005 & 0.006 & 0.004 & 0.004 & 0.007 & 0.007 & 0.001 \\
\hline
\end{tabular}

Note: MEP - meat; VOL - vegetable oil; MIL - milk; GOG - grain; SUG - sugar; OTF - other food; ADT alcohol, drinks and tobacco.

The greater the food production output, the more energy input required, as indicated by the results in Table 7 . Grain is not included as one of the top three food products requiring the most energy. Instead, the top three are sugar, meat and vegetable. These three food products benefit from the increases of all types of energy by approximately $0.024 \%, 0.021 \%$ and $0.020 \%$, respectively in S1. S2 has similar results, though with lower values, thus supporting $\mathrm{H} 2$, which states that a drought-exempt case or a flood-exempt case will increase the demand of food production for energy input. Therefore, $\mathrm{H} 2$ is accepted.

\subsubsection{Impacts on Households}

Table 8. Change in food consumption, income and welfare of household

\begin{tabular}{|c|c|c|c|c|c|c|c|}
\hline \multirow{2}{*}{$\begin{array}{c}\text { Unit for consumption and income: } \\
\text { Unit for welfare: } \\
10 \text { million yuan }\end{array}$} & \multirow[b]{2}{*}{ Regions } & \multicolumn{3}{|c|}{ S1: Drought-exempt case } & \multicolumn{3}{|c|}{ S2: Flood-exempt case } \\
\hline & & Food consumption & Income & Welfare & Food consumption & Income & Welfare \\
\hline \multirow{16}{*}{16 regional rural household } & Guangdong & 0.004 & -0.041 & -0.498 & 0.001 & -0.012 & -0.153 \\
\hline & Jiangxi & 0.005 & -0.043 & -0.278 & 0.002 & -0.013 & -0.024 \\
\hline & Hainan & 0.006 & -0.044 & -0.012 & 0.002 & -0.014 & -0.005 \\
\hline & Yunnan & -0.009 & -0.063 & -2.207 & -0.002 & -0.017 & -0.498 \\
\hline & Guangxi & -0.0003 & -0.052 & -1.061 & 0.000 & -0.016 & -0.310 \\
\hline & Henan & -0.022 & -0.052 & -4.994 & -0.007 & -0.015 & -1.507 \\
\hline & Jilin & -0.011 & -0.063 & -1.547 & -0.001 & -0.014 & -0.257 \\
\hline & Anhui & -0.003 & -0.046 & -1.889 & -0.001 & -0.014 & -0.553 \\
\hline & Heilongjiang & -0.010 & -0.057 & -1.757 & -0.002 & -0.015 & -0.386 \\
\hline & Hebei & -0.014 & -0.054 & -3.647 & -0.004 & -0.015 & -0.988 \\
\hline & Hubei & 0.002 & -0.044 & -1.038 & 0.001 & -0.013 & -0.249 \\
\hline & Chongqing & -0.002 & -0.053 & -0.654 & 0.000 & -0.015 & -0.134 \\
\hline & Sichuan & 0.002 & -0.045 & -1.043 & 0.001 & -0.013 & -0.187 \\
\hline & Inner Mongolia & -0.014 & -0.057 & -1.495 & -0.003 & -0.015 & -0.355 \\
\hline & Shandong & -0.012 & -0.049 & -5.727 & -0.004 & -0.014 & -1.682 \\
\hline & Others & -0.003 & -0.045 & -18.023 & -0.001 & -0.013 & -4.723 \\
\hline \multicolumn{2}{|c|}{ Total change in rural household } & -0.004 & -0.049 & -45.871 & -0.001 & -0.014 & -12.011 \\
\hline \multicolumn{2}{|c|}{ Total change in urban household } & 0.012 & -0.005 & 79.355 & 0.003 & -0.001 & 22.355 \\
\hline
\end{tabular}

Note: "Food" in this study refers to crops and the products from food industries and includes 5 kinds of products: meat, milk, vegetable oil, gain, sugar, and other food products. 
All rural households suffer more significantly in S1 and S2, incurring greater losses in food consumption, income and welfare. Three rural household regions, however, are exceptions, demonstrating increased food consumption, including those from Guangdong, Jiangxi and Hainan. Moreover, urban households exhibit greater benefits with respect to food consumption and welfare; however, their income slightly decreases (see Table 8). Rural households in Shandong, Henan, Hebei, Yunnan, Anhui, and Heilongjiang suffer more significant losses with respect to their welfare at 57.27, 49.94, 36.47, 22.07, 18.89 and 17.57 million yuan, respectively.

Table 9. Changes in the return of land and the wage of agricultural labor

\begin{tabular}{lcccc}
\hline Unit: \% & \multicolumn{2}{c}{ S1: Drought-exempt case } & \multicolumn{2}{c}{ S2: Flood-exempt case } \\
\cline { 2 - 5 } & Returns of land & Wages of agricultural labor & Return of land & Wage of agricultural labor \\
\hline Guangdong & -1.833 & -0.058 & -0.989 & -0.017 \\
Jiangxi & -4.198 & -0.052 & -0.894 & -0.015 \\
Hainan & -0.739 & -0.061 & -3.500 & -0.019 \\
Yunnan & -3.748 & -0.076 & -1.902 & -0.020 \\
Guangxi & -3.017 & -0.058 & -1.047 & -0.017 \\
Henan & -2.039 & -0.063 & -1.613 & -0.018 \\
Jilin & -18.407 & -0.069 & -0.552 & -0.017 \\
Anhui & -1.205 & -0.054 & -4.086 & -0.016 \\
Heilongjiang & -12.059 & -0.061 & -0.443 & -0.017 \\
Hebei & -4.826 & -0.070 & -3.362 & -0.019 \\
Hubei & -2.965 & -0.056 & -3.743 & -0.016 \\
Chongqing & -3.237 & -0.067 & -3.257 & -0.019 \\
Sichuan & -3.180 & -0.053 & -2.284 & -0.015 \\
Inner Mongolia & -17.803 & -0.060 & -0.719 & -0.016 \\
Shandong & -2.051 & -0.062 & -0.761 & -0.018 \\
Others & -5.409 & -0.061 & -1.402 & -0.018 \\
\hline
\end{tabular}

The different levels of welfare are determined by the changes in consumption, which are further controlled by income. With the fixed amount of regional lands and agricultural labor in this model, all decreases in the returns of land and in the wages of agricultural labor reduce the income of 16 regional rural households, especially for those rural households located in Jilin, Inner Mongolia and Heilongjiang, whose returns of cropland decrease by $18.407 \%, 17.803 \%$ and $12.509 \%$, respectively (see Table 9). If the drought-exempt case or the flood-exempt case is presented as one kind of good harvest, these results support an old finding that a good harvest may reduce the farmer's income due to the lower returns associated with their croplands. Therefore, H3 is also accepted.

\section{Conclusion}

By applying the CGE-Energy model in the social accounting matrix of a macro economy with multi-regional sectors, including water demand and supply, cropland, agricultural labor and rural households, this study measured the effects of a drought-exempt case and a flood-exempt case in the worst year for droughts by testing three hypotheses. The real GDP obtains an insignificant positive effect contributed by the increase in agricultural outputs, while all other macro economy indices would be slightly worse, such as a nominal GDP, consumer price index and total consumption as well as total export and total import. The results indicate that in both cases, all agricultural productions increase their outputs and exports, but selling prices and the imports of agricultural products decrease. The most significant three crops in output were sorghum, oil seed and corn because their productions collected more cropland than others. Potato was also cultivated with more cropland, but its increase in output was not more significant than the aforementioned three crops. Another finding was that by investing more land to crop production, more capital and less labor would be required by most of the crops. Accordingly, the released labor could be redistributed into non-crop agricultural productions including livestock, forestry, fishery and service for agriculture. The increase in food production was also evident in the results with the most 
three significant outputs occurring in sugar, meat and vegetable oil. The energy input in their production, however, was also greater than that for food products. All exports of food products increased while their domestic prices and imports decreased. Therefore, households would benefit from the lower prices of all agricultural and food products supplied by more domestic outputs and fewer imports. Only urban households benefit from increased food consumption and higher welfare, while rural households would not benefit due to the declines in the returns on cropland and in the wages for agricultural labor. The rural households demonstrating the greatest negative change in welfare are from Shandong, Henan, Hebei, Yunnan, Anhui, and Heilongjiang. This result reveals an old finding that a good harvest may reduce a farmer's income because of a lower return on cropland. Therefore, if the government and farmers aim to protect their losses in harvest from natural hazards, they must prevent the decline in the return of cropland, an issue that should be considered during policy recommendations.

In general, because the results derived from CGE model may be significantly dependent on exogenous parameters, the sensitivity analysis should be performed to guarantee the robustness of model (Harrison, Jones, Kimbell \& Wigle, 1993). In this study, we did not carry out the sensitivity analysis, since all given parameters were derived from previous studies (Ge et al., 2014; Willenbockel, 2006; Zhai \& Hertel, 2005), where the sensitivity analysis on these parameters were already discussed. We admit that several parameters might be too imprecise to reflect the reality, such as the elasticity values of the CES function for the regional land and water composite and the Cobb-Douglas assumption for regional agricultural labor. But because of data limitations, we must accept these parameters. In addition, previous CGE studies suggested that further detailed analysis, based on disaggregated sectors and/or space, can reveal a more thorough and comprehensive figure of disaster impacts (Okuyama \& Sahin, 2009). In this study, however, as our assumption regards only adjustments in regional total amount of cropland, the multiplier effects of droughts and floods were underestimated. In addition, according to the our interview survey on farmers, they always complain that the existing compensated supports, such as disaster subsidy and agricultural insurance, are not enough for compensating their losses in droughts and floods. However, it is obviously difficult for government to measure the actual losses on farmers' welfare. This study provides two simulations --- drought-exempt and flood-exempt to estimate the effects on the households' welfare While future research could provide more detailed data regarding the impacts of droughts and floods, we will consider improving our simulation for policy instruments in future by introducing new simulation designs with respect to markets, risk mitigation, technical change, value chain integration and insurance and so on.

\section{Acknowledgements}

The authors appreciate the cooperation of Professor Jianping GE for permitting us to use his social accounting matrix.

\section{Reference}

Akune, Y., Okiyama, M., \& Tokunaga, S. (2011). Applied general equilibrium model using for the elimination of the tariffs of agricultural products in Japan. Paper presented at The 48th Annual Meeting of The Japan Section of the RSAI, 8-10 October 2011: Wakayama, Japan.

Armington, P. S. (1969). A theory of demand for products distinguished by place of production (Une Théorie De La Demande De Produits Différenciés D'après Leur Origine)(Una Teoría De La Demanda De Productos Distinguiéndolos Según El Lugar De Producción). Staff Papers-International Monetary Fund, 159-178. Retrieved from http://www.jstor.org/stable/10.2307/3866403

Beckman, J., Hertel, T., \& Tyner, W. (2011). Validating energy-oriented CGE models. Energy Economics, 33(5), 799-806. http://dx.doi.org/10.1016/j.eneco.2011.01.005

Burniaux, J. M., \& Truong, T. P. (2002). GTAP-E: an energy-environmental version of the GTAP model. GTAP Technical Papers, 18. Retrieved from http://docs.lib.purdue.edu/gtaptp/18

Calzadilla, A., Rehdanz, K., \& Tol, R. S. (2011). The GTAP-W Model: accounting for water use in agriculture (No. 1745). Kiel Working Papers. Retrieved from http://hdl.handle.net/10419/54939

Chen, Z., \& Yang, G. (2013). Analysis of drought hazards in north China: distribution and interpretation. Natural Hazards, 65(1), 279-94. Retrieved from http://link.springer.com/article/10.1007/s11069-012-0358-3

CIESIN \& SEDAC. (1997-2009). Agriculture Statistics of People's Republic of China: 1949-1990. Variable Definition Overview. Available by Center for International Earth Science Information Network, Socioeconomic Data and Applications Center. Retrieved from http://sedac.ciesin.org/china/econ/agr/agr_def.html 
Dawe, D. (2009). The unimportance of "low" world grain stocks for recent world price increases. Agricultural Development Economics Division, The Food and Agriculture Organization of the United Nations ESA Working paper, (09-01).

EcoMod Modeling School. (2013). Environmental CGE model with GAMS. Global Economic Modeling Network, Singapore, January 21-25, 2013.

Ge, J., Lei, Y., \& Tokunaga, S. (2014). Non-grain fuel ethanol expansion and its effects on food security: A computable general equilibrium analysis for China. Energy, 65(1), 346-356. http://dx.doi.org/10.1016/j.energy.2013.10.093.

Ge, J., \& Tokunaga, S. (2011). Impacts of expanding non-grain based fuel ethanol on regional equality in China: using a computable general equilibrium model. Studies in Regional Science, 41(4), 883-896. http://dx.doi.org/10.2457/srs.41.883

Godfray, H. C. J., Beddington, J. R., Crute, I. R., Haddad, L., Lawrence, D., Muir, J. F., ... Toulmin, C. (2010). Food security: the challenge of feeding 9 billion people. Science, 327(5967), 812-818. http://dx.doi.org/10.1126/science.1185383

Harrison, G. W., Jones, R., Kimbell, L. J., \& Wigle, R. (1993). How robust is applied general equilibrium analysis? Journal of Policy Modeling, 15(1), 99-115. http://dx.doi.org/10.1016/0161-8938(93)90024-K.

Harvey, M., \& Pilgrim, S. (2011). The new competition for land: food, energy, and climate change. Food Policy, 36, S40-S51. http://dx.doi.org/10.1016/j.foodpol.2010.11.009

Hosoe, N., Gasawa, K., \& Hashimoto, H. (2010). Textbook of Computable General Equilibrium Modeling: Programming and Simulations. Palgrave Macmillan.

Li, S. (2012). China's huge investment on water Facilities: an effective adaptation to climate change, natural disasters, and food security. Natural Hazards, 61(3), 1473-75. http://dx.doi.org/10.1007/s11069-011-9964-8

Liu, Y., Yang Y., \& Li, L. I. (2012). Major natural disasters and their spatio-temporal variation in the history of China. Journal of Geographical Sciences, 22(6), 963-976. http://dx.doi.org/10.1007/s11442-012-0976-4

Lucas, C., Jones, A., \& Hines, C. (2007). Fueling a Food Crisis: The Impact of Peak Oil on Food Security. London: Greens / European Free Alliance / European Parliament.

National Bureau of Statistics of China [NBSC]. (2008b). China Statistic Yearbook 2003-2012, Beijing: China Statistics Press.

National Bureau of Statistics of China [NBSC]. (2011). China Regional Input-Output 2007, China Statistics Press, Beijing.

National Bureau of Statistics of China [NBSC]. (2008a). China Agricultural Yearbook 2001-2008, China Statistics Press, Beijing.

National Bureau of Statistics of China [NBSC]. (2012). China Rural Statistical Yearbook 2007-2012, National Bureau of Statistics of China. Retrieved from www.stats.gov.cn (accessed 14 August 2013).

National Development and Reform Commission of China [NDRCC]. (2008). National Data Compilation of Revenue and Cost of Agricultural Products 2008, China Statistics Press, Beijing.

Nijkamp, P., Wang, S., \& Kremers, H. (2005). Modeling the impacts of international climate change policies in a CGE context: The use of the GTAP-E model. Economic Modelling, 22(6), 955-974. http://dx.doi.org/10.1016/j.econmod.2005.06.001

Okiyama, M., \& Tokunaga, S. (2010). Impact of expanding bio - Fuel consumption on household income of farmers in Thailand: utilizing the computable general equilibrium model. Review of Urban \& Regional Development Studies, 22(2-3), 109-142. http://dx.doi.org/10.1111/j.1467-940X.2010.00172.x

Okuyama, Y., \& Sahin, S. (2009). Impact Estimation of Disasters. Research Working papers, 1(1), 1-42. http://dx.doi.org/ 10.1596/1813-9450-4963.

Palatnik, R. R., \& Roson, R. (2012). Climate change and agriculture in computable general equilibrium models: alternative modeling strategies and data needs. Climatic Change, 112(3-4), 1085-1100. http://dx.doi.org/10.1007/s10584-011-0356-6

Simelton, E. (2011). Food self-sufficiency and natural hazards in China. Food Security, 3(1), 35-52. http://dx.doi.org /10.1007/s12571-011-0114-7 
Tokunaga, S., Resosudarmo, B. P., Wuryanto, L. E., \& Dung, N. T. (2003). An inter-regional CGE model to assess the impacts of tariff reduction and fiscal decentralization on regional economy: the case of Indonesia. Studies in Regional Science, 33(2), 1-25. http://dx.doi.org/10.2457/srs.33.2_1

Willenbockel, D. (2006). Structural effects of a real Exchange rate revaluation in China: a CGE assessment. Retrieved from http://ssrn.com/abstract=945562 or http://dx.doi.org/10.2139/ssrn.945562

Yang, H., \& Li, X. (2000). Cultivated land and food supply in China. Land Use Policy, 17(2), 73-88. http://dx.doi.org/10.1016/S0264-8377(00)00008-9

Zhai, F., \& Hertel, T. (2005). Impacts of the DDA on China: the role of labor markets and complementary education reforms. Poverty and the WTO. Impact of the Doha Development Agenda, Palgrave Macmillan: United Kingdom and World Bank: Washington DC, 285-318.

Zhao, J., Luo, Q., Deng, H., \& Yan, Y. (2008). Opportunities and challenges of sustainable agricultural development in China. Philosophical Transactions of the Royal Society B: Biological Sciences, 363(1492), 893-904. http://dx.doi.org /10.1098/rstb.2007.2190

Zhao, Y., \& Wang, J. (2008). CGE Model and Its Applications in Economic Analysis. Beijing, China: China Economic Press, 196

Zhong, S., Okiyama, M., \& Tokunaga, S. (2013). Impact of water scarcity on food consumption and agricultural production in China: a general equilibrium analysis. Paper presented at The 2013 Annual Meeting of The Agricultural Economics Society of Japan, 39-30 March, Tokyo, Japan. 


\section{Appendix 1. CGE-Energy Model}

\section{Equations}

\subsection{Household}

1.1.1 Consumption

$$
\begin{gathered}
\mathrm{P}_{\text {sec }} \cdot \mathrm{C}_{\text {sec,hou }}=\mathrm{P}_{\text {sec }} \cdot \mu \mathrm{H}_{\text {sec,hou }}+\alpha \mathrm{HLES}_{\text {sec,hou }} \cdot\left(\mathrm{CBUD}_{\text {hou }}-\sum_{\text {sec }} \mathrm{P}_{\text {sec }} \cdot \mu \mathrm{H}_{\text {sec,hou }}\right) \\
\mathrm{SH}_{\text {hou }}=\mathrm{mps}_{\text {hou }} \cdot\left(\mathrm{Y}_{\text {hou }}-\mathrm{ty}_{\text {hou }} \cdot \mathrm{Y}_{\text {hou }}\right)
\end{gathered}
$$

1.1.2 Income of Household: Rural

$$
\begin{aligned}
& \mathrm{Y}_{\text {hour }}=\mathrm{PLAN}_{\text {lad }} \cdot \overline{\mathrm{LANS}}_{\text {lad }}+\mathrm{PL} \_\mathrm{RA}_{\text {laa }} \cdot \overline{\mathrm{LARS}}_{\text {laa }}+\mathrm{PK} \cdot \overline{\mathrm{KH}}_{\text {hour }}+\mathrm{ER} \cdot \overline{\mathrm{FH}}_{\text {hour }}+\mathrm{PCINDEX} \cdot\left(\overline{\mathrm{TRF}}_{\text {hour }}+\right. \\
& \overline{\text { TRE }}_{\text {hour }} \text { ) }
\end{aligned}
$$

1.1.3 Income of Household: Urban

$$
\mathrm{Y}_{\mathrm{URBH}}=\overline{\mathrm{PLNA}} \cdot \overline{\mathrm{LNAS}}_{\mathrm{URBH}}+\mathrm{PK} \cdot \overline{\mathrm{KH}}_{\mathrm{URBH}}+\mathrm{ER} \cdot \overline{\mathrm{FH}}_{\mathrm{URBH}}+\mathrm{PCINDEX} \cdot\left(\overline{\mathrm{TRF}}_{\mathrm{URBH}}+\overline{\mathrm{TRE}}_{\mathrm{URBH}}\right)
$$

1.1.4 Consumer Expenditure

$$
\operatorname{CBUD}_{\text {hou }}=\left(1-\mathrm{ty}_{\text {hou }}\right) \cdot \mathrm{Y}_{\text {hou }}-\mathrm{SH}_{\text {hou }}
$$

1.1.5 Equivalent and Compensating Variation

$$
\begin{aligned}
& \text { PLES }_{\text {hou }}=\prod_{\text {sec }} \mathrm{P}_{\text {sec }}{ }^{\alpha \mathrm{HLES}_{\text {sec }} \text { hou }} \\
& \text { PLES_10 }{ }_{\text {hou }}=\text { PLES }_{\text {hou }} / \text { PLES }_{\text {hou }}^{0} \\
& \mathrm{SI}_{\text {hou }}=\mathrm{CBUD}_{\text {hou }}-\sum_{\text {sec }} \mu \mathrm{H}_{\text {sec,hou }} \cdot \mathrm{P}_{\text {sec }} \\
& \mathrm{EV}=\frac{\mathrm{SI}_{\text {hou }}}{\mathrm{PLES}_{-} 10_{\text {hou }}}-\mathrm{SI}_{\text {hou }}^{0} \\
& \mathrm{CV}=\mathrm{SI}_{\text {hou }}-\mathrm{PLES}_{-} 10_{\text {hou }} \cdot \mathrm{SI}_{\text {hou }}^{0}
\end{aligned}
$$

1.2 Enterprise

$$
\begin{gathered}
\mathrm{YE}=\mathrm{PK} \cdot \overline{\mathrm{EK}} \\
\mathrm{SE}=\mathrm{mpe} \cdot(\mathrm{YE}-\mathrm{tye} \cdot \mathrm{YE})
\end{gathered}
$$

\subsection{Firms}

1.3.1 Agriculture: Crop

$$
\begin{aligned}
& \mathrm{KLW}_{\text {cro }}=\left(\frac{\mathrm{XD}_{\text {cro }}}{\mathrm{aVA}_{\text {cro }}}\right) \cdot\left(\frac{\alpha \mathrm{KLW} \cdot \mathrm{PL}_{\text {cro }}}{\alpha \mathrm{L}_{\text {cro }} \cdot \mathrm{PKLW}_{\text {cro }}}\right)^{\alpha \mathrm{L}_{\text {cro }}}
\end{aligned}
$$

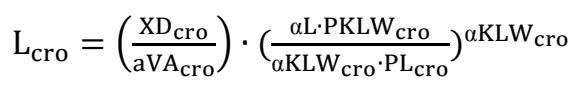

$$
\begin{aligned}
& \mathrm{K}_{\mathrm{cro}}= \\
& \left(\frac{\mathrm{KLW}_{\mathrm{cro}}}{\mathrm{aKLW}_{\mathrm{cro}}}\right) \cdot\left(\frac{\gamma \mathrm{KLW}_{\mathrm{cro}}}{\mathrm{PK}}\right)^{\sigma \mathrm{KLW} \text { cro }} \text {. } \\
& \left(\gamma \mathrm{KLW}_{\text {cro }}{ }^{\sigma K L W_{\text {cro }}} \cdot \mathrm{PK}^{1-\sigma K L W_{\text {cro }}}+\left(1-\gamma \mathrm{KLW}_{\text {cro }}\right)^{\sigma \mathrm{KLW}_{\text {cro }}} \cdot \mathrm{PLAWA}^{1-\sigma K L W_{\text {cro }}}\right)^{\sigma \mathrm{KLW}_{\text {cro }} /\left(1-\sigma \mathrm{KLW}_{\text {cro }}\right)} \\
& \mathrm{LAWA}_{\text {cro }}=\left(\frac{\mathrm{KLW}_{\text {cro }}}{\mathrm{aKLW}_{\text {cro }}}\right) \cdot\left(\frac{1-\gamma \mathrm{KLW}_{\text {cro }}}{\mathrm{PLAWA}}\right)^{\sigma \mathrm{KLW}_{\text {cro }}} \cdot\left(\gamma \mathrm{KLW}_{\text {cro }}{ }^{\sigma \mathrm{KLW}} \mathrm{Cro}_{\text {cro }} \cdot \mathrm{PK}^{1-\sigma \mathrm{KLW}_{\text {cro }}}+\left(1-\gamma \mathrm{KLW}_{\text {cro }}\right)^{\sigma \mathrm{KLW}_{\text {cro }}} \cdot\right. \\
& \left.\operatorname{PLAWA}^{1-\sigma \mathrm{KLW}_{\text {cro }}}\right)^{\sigma \mathrm{KLW}_{\text {cro }} /\left(1-\sigma \mathrm{KLW}_{\text {cro }}\right)} \\
& \mathrm{LAWAR}_{\text {was,cro }} \cdot \mathrm{PLAWAR}_{\text {was,cro }}=\alpha \mathrm{LW}_{\text {was,cro }} \cdot \mathrm{PLAWA}_{\text {cro }} \cdot \mathrm{LAWA}_{\text {cro }}
\end{aligned}
$$




$$
\begin{aligned}
& \mathrm{WAT}_{\text {was,cro }}=\left(\frac{\mathrm{LAWAR}_{\text {was,cro }}}{\mathrm{aRLW}_{\text {was }, \text { cro }}}\right) \cdot\left(\frac{\gamma \mathrm{LW}_{\text {was,cro }}}{\mathrm{P}_{\text {was }}}\right)^{\sigma \mathrm{LW}_{\text {cro }}} \\
& \cdot\left(\gamma \mathrm{LW}_{\text {was,cro }} \sigma \mathrm{LW}_{\text {cro }} \cdot \mathrm{P}_{\text {was }}{ }^{1-\sigma \mathrm{LW}_{\text {cro }}}+\left(1-\gamma \mathrm{LW}_{\mathrm{was}, \mathrm{cro}}\right)^{\sigma \mathrm{LW}_{\text {cro }} \cdot \mathrm{PLAN}_{\mathrm{lad}} 1-\sigma \mathrm{LW}_{\mathrm{cro}}}\right)^{\frac{\sigma \mathrm{LW}_{\text {cro }}}{1-\sigma \mathrm{LW}_{\text {cro }}}} \\
& \mathrm{LANR}_{\text {lad,cro }}=\left(\frac{\mathrm{LAWAR}_{\text {was,cro }}}{\mathrm{aRLW}_{\mathrm{was}, \mathrm{cro}}}\right) \cdot\left(\frac{1-\gamma \mathrm{LW}_{\text {was,cro }}}{\mathrm{PLAN}_{\text {lad }}}\right)^{\sigma \mathrm{LW}_{\text {cro }}} \\
& \mathrm{K}_{\mathrm{ncro}}=\left(\frac{\mathrm{XD}_{\text {ncro }}}{\mathrm{aVA}_{\text {ncro }}}\right) \cdot\left(\frac{\alpha \mathrm{K}_{\text {ncro }} \cdot \mathrm{PL}_{\mathrm{ncro}}}{\alpha \mathrm{L}_{\mathrm{ncro}} \cdot \mathrm{PK}_{\mathrm{ncro}}}\right)^{\alpha \mathrm{L}_{\text {ncro }}} \\
& \mathrm{L}_{\mathrm{ncro}}=\left(\frac{\mathrm{XD}_{\mathrm{ncro}}}{\mathrm{aVA} \mathrm{A}_{\mathrm{ncro}}}\right) \cdot\left(\frac{\alpha \mathrm{L}_{\mathrm{ncro}} \cdot \mathrm{PK}_{\mathrm{ncro}}}{\alpha \mathrm{K}_{\mathrm{ncro}} \cdot \mathrm{PL}_{\mathrm{ncro}}}\right)^{\alpha \mathrm{K}_{\mathrm{ncro}}}
\end{aligned}
$$

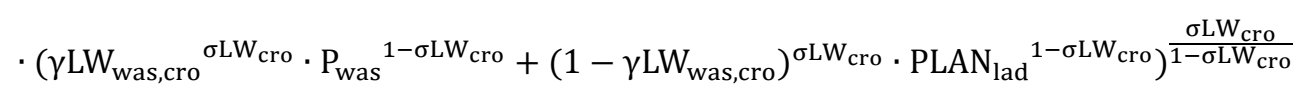

1.3.3 Agriculture: Labor

$$
\begin{aligned}
& \mathrm{L}_{-} \mathrm{A}_{\mathrm{agc}}= \\
& \left(\mathrm{L}_{\mathrm{agc}} / \mathrm{aLB}_{\mathrm{agc}}\right) \cdot\left(\frac{\gamma \mathrm{LB} \mathrm{Bgc}_{\mathrm{ag}}}{\mathrm{PL}_{-} \mathrm{A}_{\mathrm{agc}}}\right)^{\sigma \mathrm{LB} \mathrm{agc}} \text {. }
\end{aligned}
$$

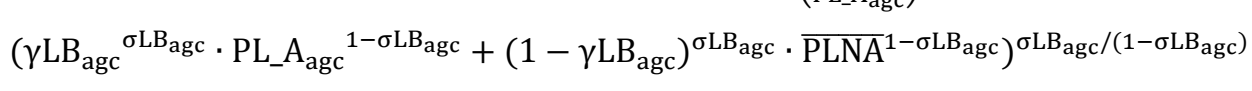

$$
\begin{aligned}
& \mathrm{LNA}_{\mathrm{agc}}= \\
& \left(\mathrm{L}_{\mathrm{agc}} / \mathrm{aLB}_{\mathrm{agc}}\right) \cdot\left(\frac{1-\gamma \mathrm{LB} \mathrm{agc}}{\overline{\mathrm{PLNA}}}\right)^{\sigma \mathrm{LB} \mathrm{agc}} \text {. }
\end{aligned}
$$

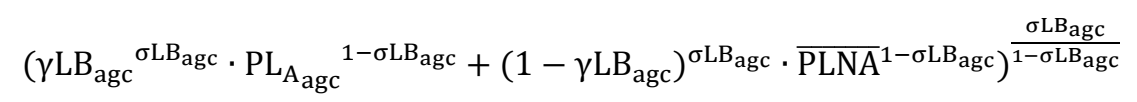

$$
\begin{aligned}
& \text { PL_RA } A_{\text {laa }} \cdot L_{-} \mathrm{RA}_{\text {laa,agc }}=\alpha \mathrm{LB}_{\text {laa }, \mathrm{agc}} \cdot \mathrm{PL} \_\mathrm{A}_{\mathrm{agc}} \cdot \mathrm{L} \_\mathrm{A}_{\mathrm{agc}}
\end{aligned}
$$

1.3.4 Zero Profit Condition: Crop

$$
\begin{aligned}
& \left(1-\mathrm{tp}_{\mathrm{cro}}\right) \cdot \mathrm{PD}_{\text {cro }} \cdot \mathrm{XD}_{\text {cro }}=\mathrm{PL}_{\text {cro }} \cdot \mathrm{L}_{\text {cro }}+\mathrm{PKLW}_{\text {cro }} \cdot \mathrm{KLW}_{\text {cro }}+\left(\sum_{\mathrm{agc}} \mathrm{io}_{\mathrm{agc,cro}} \cdot \mathrm{XD}_{\text {cro }} \cdot \mathrm{P}_{\mathrm{agc}}\right)+\left(\sum_{\text {foe }} \mathrm{io}_{\text {foe,cro }} \cdot\right. \\
& \left.\mathrm{XD}_{\text {cro }} \cdot \mathrm{P}_{\text {foe }}\right)+\left(\sum_{\text {ots }} \text { io }_{\text {ots,cro }} \cdot \mathrm{XD}_{\text {cro }} \cdot \mathrm{P}_{\text {ots }}\right) \\
& \mathrm{PKLW}_{\text {cro }} \cdot \mathrm{KLW}_{\text {cro }}=\mathrm{PK}_{\text {cro }} \cdot \mathrm{K}_{\text {cro }}+\mathrm{PLAWA}_{\text {cro }} \cdot \mathrm{LAWA}_{\text {cro }} \\
& \mathrm{LAWA}_{\text {cro }}=\mathrm{aLW}_{\text {cro }} \cdot \prod_{\text {was }} \operatorname{PLAWAR}_{\text {was,cro }} \alpha \mathrm{LW}_{\text {was,cro }} \text {. } \\
& \text { PLAWAR }_{\text {was,cro }} \cdot \mathrm{LAWAR}_{\text {was,cro }}=\mathrm{P}_{\text {was }} \cdot \mathrm{WAT}_{\text {was,cro }}+\mathrm{PLAN}_{\text {lad }} \cdot \mathrm{LANR}_{\text {lad,cro }}
\end{aligned}
$$

1.3.5 Zero Profit Condition: Non-crop and Labor

$$
\begin{aligned}
& \left(1-\mathrm{tp}_{\mathrm{ncro}}\right) \cdot \mathrm{PD}_{\mathrm{ncro}} \cdot \mathrm{XD}_{\mathrm{ncro}}=\mathrm{PL}_{\mathrm{ncro}} \cdot \mathrm{L}_{\mathrm{ncro}}+\mathrm{PK}_{\mathrm{ncro}} \cdot \mathrm{K}_{\mathrm{ncro}}+\sum_{\mathrm{agc}} \text { io } \mathrm{agc,ncro} \cdot \mathrm{XD}_{\mathrm{ncro}} \cdot \mathrm{P}_{\mathrm{agc}} \\
& +\sum_{\text {foe }} \text { io }_{\text {foe,ncro }} \cdot \mathrm{XD}_{\text {ncro }} \cdot \mathrm{P}_{\text {foe }}+\sum_{\text {ots }} \mathrm{io}_{\mathrm{wts} \text {,ncro }} \cdot \mathrm{XD}_{\text {ncro }} \cdot \mathrm{P}_{\mathrm{wts}}
\end{aligned}
$$




$$
\begin{gathered}
\mathrm{PL}_{\mathrm{agc}} \cdot \mathrm{L}_{\mathrm{agc}}=\mathrm{PL} \_A_{\mathrm{agc}} \cdot \mathrm{L}_{-} \mathrm{A}_{\mathrm{agc}}+\overline{\mathrm{PLNA}} \cdot \mathrm{LNA}_{\mathrm{agc}} \\
{\mathrm{L} \_\mathrm{A}_{\text {agc }}}=\mathrm{aRLB}{ }_{\mathrm{agc}} \cdot \prod_{\text {laa }} \mathrm{L} \_\mathrm{RA}_{\text {laa,agc }} \alpha \mathrm{LB}
\end{gathered}
$$

1.3.6 Food and Energy

$$
\begin{aligned}
& \mathrm{KLE}_{\text {foe }}=\mathrm{aVA}_{\text {foe }} \cdot \mathrm{XD}_{\text {foe }} \\
& \mathrm{LNA}_{\text {foe }}=\left(\frac{\mathrm{KLE}_{\text {foe }}}{\mathrm{aKLE}_{\text {foe }}}\right) \cdot\left(\gamma \mathrm{KLE}_{\text {foe }} / \overline{\mathrm{PLNA}}\right)^{\sigma \mathrm{KLE}} \mathrm{foe}_{\text {foe }} \cdot\left(\gamma \mathrm{KLE}_{\text {foe }}{ }^{\sigma \mathrm{KLE}_{\text {foe }}} \cdot{\overline{\mathrm{PLNA}^{1}}}^{1-\sigma \mathrm{KLE}_{\text {foe }}}+\left(1-\gamma \mathrm{KLE}_{\text {foe }}\right)^{\sigma \mathrm{KLE}} \mathrm{foe}_{\text {foe }} \cdot\right. \\
& \left.\mathrm{PKE}_{\text {foe }}{ }^{1-\sigma K L E_{\text {foe }}}\right)^{\sigma K L E_{\text {foe }} /\left(1-\sigma K L E_{\text {foe }}\right)} \\
& \mathrm{KE}_{\text {foe }}= \\
& \left(\frac{\mathrm{KLE}_{\text {foe }}}{\mathrm{aKLE}_{\text {foe }}}\right) \cdot\left(\left(1-\gamma \mathrm{KLE}_{\text {foe }}\right) / \mathrm{PKE}_{\text {foe }}\right)^{\sigma K L E_{\text {foe }}} \cdot\left(\gamma \mathrm{KLE}_{\text {foe }}{ }^{\sigma \mathrm{KLE}_{\mathrm{foe}}} \cdot \overline{\mathrm{PLNA}}^{1-\sigma K L E_{\text {foe }}}+\left(1-\gamma \mathrm{KLE}_{\mathrm{foe}}\right)^{\sigma \mathrm{KLE}_{\text {foe }}} \cdot\right. \\
& \left.\mathrm{PKE}_{\mathrm{foe}}{ }^{1-\sigma K L E_{\text {foe }}}\right)^{\sigma \mathrm{KLE}} \text { foe } /\left(1-\sigma \mathrm{KLE}_{\mathrm{foe}}\right)
\end{aligned}
$$

$\mathrm{ENG}_{\text {foe }}=\left(\frac{\mathrm{KE}_{\text {foe }}}{\mathrm{aKE}_{\text {foe }}}\right) \cdot\left(\gamma \mathrm{KE}_{\text {foe }} / \mathrm{PENG}_{\text {foe }}\right)^{\sigma \mathrm{KE}_{\text {foe }}} \cdot\left(\gamma \mathrm{KE}_{\text {foe }}{ }^{\sigma \mathrm{KE}_{\text {foe }}} \cdot \mathrm{PENG}^{1-\sigma \mathrm{KE}_{\text {foe }}}+\left(1-\gamma \mathrm{KE}_{\text {foe }}\right)^{\sigma \mathrm{KE}_{\text {foe }}} \cdot\right.$$$
\left.\mathrm{PK}^{1-\sigma K E_{\text {foe }}}\right)^{\sigma K E_{\text {foe }} /\left(1-\sigma \mathrm{KE}_{\text {foe }}\right)}
$$$$
K_{\text {foe }}=\left(\frac{K_{\text {foe }}}{\mathrm{aKE}_{\text {foe }}}\right) \cdot\left(\left(1-\gamma \mathrm{KE}_{\text {foe }}\right) / \mathrm{PK}\right)^{\sigma \mathrm{KE}} \mathrm{foe}_{\mathrm{fo}}
$$

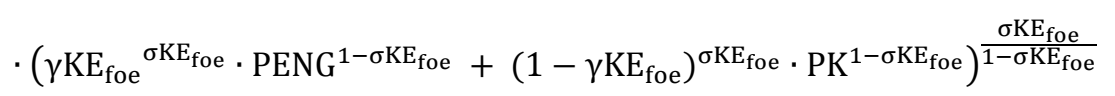$$
\mathrm{NOE}_{\text {foe }}=\left(\mathrm{ENG}_{\text {foe }} / \mathrm{aENG}_{\text {foe }}\right) \cdot\left(\alpha N O E_{\text {foe }} \cdot \mathrm{P}_{\text {foe }} /\left(\alpha E L G_{\text {foe }} \cdot \mathrm{PNOE}_{\text {foe }}\right)\right)^{\alpha \mathrm{ELG}_{\text {foe }}}
$$$$
\mathrm{ELG}_{\text {foe }}=\left(\mathrm{ENG}_{\text {foe }} / \mathrm{aENG}_{\text {foe }}\right) \cdot\left(\alpha \mathrm{ELG}_{\text {foe }} \cdot \mathrm{PNOE}_{\text {foe }} /\left(\alpha N O E_{\text {foe }} \cdot \mathrm{P}_{\text {foe }}\right)\right)^{\alpha N O E_{\text {foe }}}
$$$$
\mathrm{COA}_{\text {foe }}=
$$$$
\left(\frac{\mathrm{NOE}_{\text {foe }}}{\mathrm{aNOE}_{\mathrm{foe}}}\right) \cdot\left(\frac{\gamma \mathrm{NOE}_{\text {foe }}}{\mathrm{P}_{\mathrm{COA}}}\right)^{\sigma \mathrm{NOE}_{\text {foe }}} .
$$

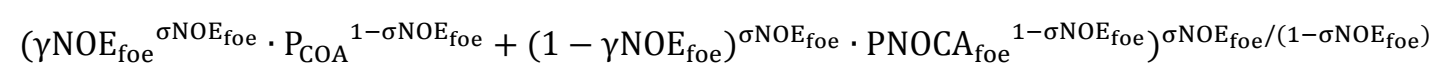

$$
\begin{aligned}
& \mathrm{NOCA}_{\text {foe }}=\left(\frac{\mathrm{NOE}_{\text {foe }}}{\mathrm{aNOE}_{\mathrm{foe}}}\right) \cdot\left(\frac{1-\gamma \mathrm{NOE}_{\text {foe }}}{\mathrm{PNOCA}_{\text {foe }}}\right)^{\sigma \mathrm{NOE}_{\mathrm{foe}}} \cdot\left(\gamma \mathrm{NOE}_{\mathrm{foe}}{ }^{\sigma N O E_{\text {foe }}} \cdot \mathrm{P}_{\mathrm{COA}}{ }^{1-\sigma N O E_{\text {foe }}}+\left(1-\gamma \mathrm{NOE}_{\mathrm{foe}}\right)^{\sigma N O E_{\text {foe }}} \cdot\right. \\
& \text { PNOCA } \left._{\text {foe }}{ }^{1-\sigma N O E_{\text {foe }}}\right)^{\sigma N O E_{\text {foe }} /\left(1-\sigma N O E_{\text {foe }}\right)} \\
& \mathrm{PET}_{\text {foe }}=\left(\mathrm{NOCA}_{\text {foe }} / \mathrm{aNOCA}_{\text {foe }}\right) \cdot\left(\alpha \mathrm{PET}_{\text {foe }} \cdot \mathrm{P}_{\mathrm{GAO}} /\left(\alpha \mathrm{GAO} \text { foe } \cdot \mathrm{P}_{\mathrm{PET}}\right)\right)^{\alpha \mathrm{GAO}_{\text {foe }}} \\
& \mathrm{GAO}_{\text {foe }}=\left(\mathrm{NOCA}_{\text {foe }} / \mathrm{aNOCA}_{\text {foe }}\right) \cdot\left(\alpha \mathrm{GAO}_{\text {foe }} \cdot \mathrm{P}_{\mathrm{PET}} /\left(\alpha \mathrm{PET}_{\text {foe }} \cdot \mathrm{P}_{\mathrm{GAO}}\right)\right)^{\alpha \mathrm{PET}_{\text {foe }}}
\end{aligned}
$$

1.3.7 Zero Profit Condition: Food and Energy

$$
\begin{gathered}
\left(1-\mathrm{tp}_{\text {foe }}\right) \cdot \mathrm{PD}_{\text {foe }} \cdot \mathrm{XD}_{\text {foe }}=\mathrm{PKLE}_{\text {foe }} \cdot \mathrm{KLE}_{\text {foe }}+\sum_{\mathrm{agc}} \mathrm{io}_{\mathrm{agc}, \text { foe }} \cdot \mathrm{XD}_{\text {foe }} \cdot \mathrm{P}_{\mathrm{agc}}+\sum_{\text {foo }} \mathrm{io}_{\text {foo,foe }} \cdot \mathrm{XD}_{\text {foe }} \cdot \mathrm{P}_{\text {foo }}+ \\
\sum_{\mathrm{wts}} \mathrm{io}_{\mathrm{wts}, \text { foe }} \cdot \mathrm{XD}_{\text {foe }} \cdot \mathrm{P}_{\mathrm{wts}} \\
\mathrm{PKLE}_{\text {foe }} \cdot \mathrm{KLE}_{\text {foe }}=\overline{\mathrm{PLNA}} \cdot \mathrm{LNA}_{\text {foe }}+\mathrm{PKE}_{\text {foe }} \cdot \mathrm{KE}_{\text {foe }} \\
\mathrm{PKE}_{\text {foe }} \cdot \mathrm{KE}_{\text {foe }}=\mathrm{PK} \cdot \mathrm{K}_{\text {foe }}+\mathrm{PENG}_{\text {foe }} \cdot \mathrm{ENG}_{\text {foe }} \\
\mathrm{PENG}_{\text {foe }} \cdot \mathrm{ENG}_{\text {foe }}=\mathrm{PNOE}_{\text {foe }} \cdot \mathrm{NOE}_{\text {foe }}+\mathrm{P}_{\mathrm{ELG}} \cdot \mathrm{ELG}_{\text {foe }}
\end{gathered}
$$




$$
\begin{gathered}
\mathrm{PNOE}_{\text {foe }} \cdot \mathrm{NOE}_{\text {foe }}=\mathrm{P}_{\mathrm{COA}} \cdot \mathrm{COA}_{\text {foe }}+\mathrm{PNOCA}_{\text {foe }} \cdot \mathrm{NOCA}_{\text {foe }} \\
\mathrm{PNOCA}_{\text {foe }} \cdot \mathrm{NOCA}_{\text {foe }}=\mathrm{P}_{\mathrm{PET}} \cdot \mathrm{PET}_{\text {foe }}+\mathrm{P}_{\mathrm{GAO}} \cdot \mathrm{GAO}_{\text {foe }}
\end{gathered}
$$

1.3.8 Water and Others

$$
\begin{aligned}
& \mathrm{LNA}_{\mathrm{wts}}=\left(\frac{\mathrm{XD}_{\mathrm{wts}}}{\mathrm{aVA} A_{\mathrm{wts}}}\right) \cdot\left(\gamma \mathrm{VA}_{\mathrm{wts}} / \overline{\mathrm{PLNA}}\right)^{\sigma V A_{\mathrm{wts}}} \cdot\left(\gamma \mathrm{VA}_{\mathrm{wts}}{ }^{\sigma V A_{\mathrm{wts}}} \cdot \overline{\mathrm{PLNA}}^{1-\sigma V A_{\mathrm{wts}}}+\left(1-\gamma \mathrm{VA}_{\mathrm{wts}}\right)^{\sigma V A_{\mathrm{wts}}} .\right. \\
& \left.\mathrm{PK}^{1-\sigma V A_{\mathrm{wts}}}\right)^{\sigma V A_{\mathrm{wts}} /\left(1-\sigma V A_{\mathrm{wts}}\right)} \\
& \mathrm{K}_{\mathrm{wts}}=\left(\frac{\mathrm{XD}_{\mathrm{wts}}}{\mathrm{aVA}_{\mathrm{wts}}}\right) \cdot\left(\left(1-\gamma \mathrm{VA}_{\mathrm{wts}}\right) / \mathrm{PK}\right)^{\sigma \mathrm{VA} \mathrm{wts}_{\mathrm{ws}}} \cdot\left(\gamma \mathrm{VA}_{\mathrm{wts}}{ }^{\sigma \mathrm{VA}_{\mathrm{wts}}} \cdot \overline{\mathrm{PLNA}}^{1-\sigma V A_{\mathrm{wts}}}+\left(1-\gamma \mathrm{VA}_{\mathrm{wts}}\right)^{\sigma V A_{\mathrm{wts}}} \cdot\right. \\
& \left.\mathrm{PK}^{1-\sigma V A_{w t s}}\right)^{\sigma V A_{w t s} /\left(1-\sigma V A_{w t s}\right)}
\end{aligned}
$$

1.3.9 Zero Profit Condition: Water and Other Firms

$\left(1-\mathrm{tp}_{\mathrm{wts}}\right) \cdot \mathrm{PD}_{\mathrm{wts}} \cdot \mathrm{XD}_{\mathrm{wts}}=\overline{\mathrm{PLNA}} \cdot \mathrm{LNA}_{\mathrm{wts}}+\mathrm{PK} \cdot \mathrm{K}+\sum_{\mathrm{agc}} \mathrm{io}_{\mathrm{agc}, \mathrm{wts}} \cdot \mathrm{XD}_{\mathrm{wts}} \cdot \mathrm{P}_{\mathrm{agc}}+\sum_{\mathrm{foe}} \mathrm{io}_{\text {foe, wts }} \cdot \mathrm{XD}_{\mathrm{wts}} \cdot$

$$
\mathrm{P}_{\text {foe }}+\sum_{\mathrm{wts}} \mathrm{io}_{\mathrm{wts}, \mathrm{wts}} \cdot \mathrm{XD}_{\mathrm{wts}} \cdot \mathrm{P}_{\mathrm{wts}}
$$

1.4 Saving and Investment

$$
\begin{gathered}
\mathrm{S}=\sum_{\text {hou }} \mathrm{SH}_{\text {hou }}+\mathrm{SE}+\mathrm{SG} \cdot \mathrm{PCINDEX}+\overline{\mathrm{SF}} \cdot \mathrm{ER} \\
\mathrm{P}_{\mathrm{sec}} \cdot \mathrm{I}_{\mathrm{sec}}=\alpha \mathrm{I}_{\text {sec }} \cdot\left(\mathrm{S}-\sum_{\text {nwas }} \mathrm{P}_{\text {nwas }} \cdot \overline{\mathrm{STC}}_{\text {nwas }}-\sum_{\text {was }} \mathrm{P}_{\text {was }} \cdot \overline{\mathrm{GAW}}_{\text {was }}\right)
\end{gathered}
$$

1.5 Government

$$
\begin{gathered}
\mathrm{P}_{\mathrm{sec}} \cdot \mathrm{CG}_{\mathrm{sec}}=\alpha \mathrm{CG}_{\mathrm{sec}} \cdot\left(\mathrm{TAXR}+\overline{\mathrm{FG}} \cdot \mathrm{ER}-\left(\sum_{\mathrm{hou}} \overline{\mathrm{TRF}}_{\mathrm{hou}}+\overline{\mathrm{SG}}\right) \cdot \mathrm{PCINDEX}\right) \\
\mathrm{TAXR}=\sum_{\mathrm{hou}} \mathrm{ty}_{\mathrm{hou}} \cdot \mathrm{Y}_{\text {hou }}+\mathrm{tye} \cdot \mathrm{YE}+\sum_{\mathrm{sec}}\left(\mathrm{PD}_{\mathrm{sec}} \cdot \mathrm{tp}_{\mathrm{sec}} \cdot \mathrm{XD}_{\mathrm{sec}}+\mathrm{tm}_{\mathrm{sec}} \cdot \mathrm{M}_{\mathrm{sec}} \cdot \overline{\mathrm{PWMZ}}_{\mathrm{sec}} \cdot \mathrm{ER}\right) \\
\mathrm{SG}=\mathrm{mpg} \cdot \mathrm{TAXR}
\end{gathered}
$$

\subsection{Foreign Sector}

1.6.1 Export and the Demand of Domestic Goods (CET Function)

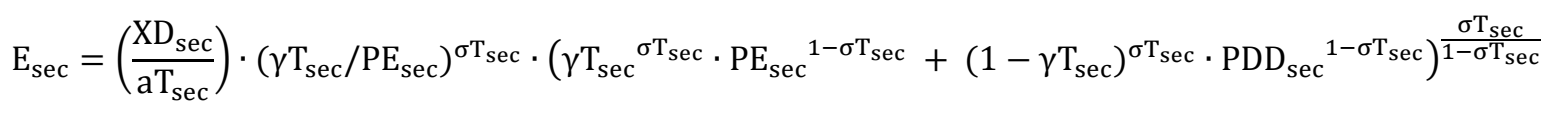

$$
\begin{aligned}
& \mathrm{XDD}_{\mathrm{sec}}=\left(\frac{\mathrm{XD}_{\mathrm{sec}}}{\mathrm{aT}_{\mathrm{sec}}}\right) \cdot\left(\left(1-\gamma \mathrm{T}_{\mathrm{sec}}\right) / \mathrm{PDD}_{\mathrm{sec}}\right)^{\sigma \mathrm{T}_{\mathrm{sec}}}
\end{aligned}
$$

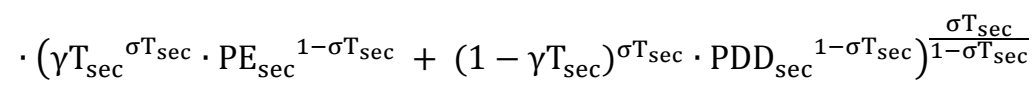

1.6.2 Zero Profit Condition: CET Function

$$
\mathrm{PD}_{\text {sec }} \cdot \mathrm{XD}_{\mathrm{sec}}=\mathrm{PE}_{\mathrm{sec}} \cdot \mathrm{E}_{\mathrm{sec}}+\mathrm{PDD}_{\mathrm{sec}} \cdot \mathrm{XDD}_{\mathrm{sec}}
$$

1.6.3 Import and the Demand of Domestic Goods (Armington Function)

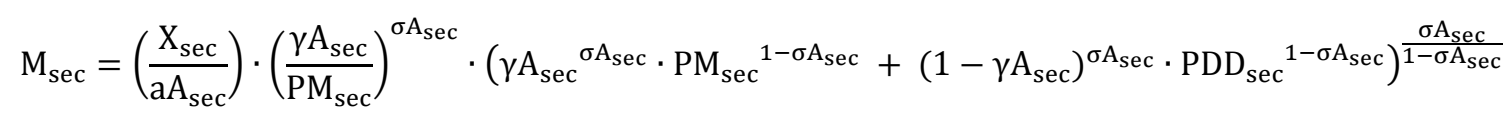




$$
\begin{aligned}
& \mathrm{XDD}_{\mathrm{sec}}= \\
& \left(\frac{\mathrm{X}_{\mathrm{sec}}}{\mathrm{aA} \mathrm{A}_{\mathrm{sec}}}\right) \cdot\left(\left(1-\gamma \mathrm{A}_{\mathrm{sec}}\right) / \mathrm{PDD}_{\mathrm{sec}}\right)^{\sigma \mathrm{A}_{\mathrm{sec}}} \cdot\left(\gamma \mathrm{A}_{\mathrm{sec}}{ }^{\sigma \mathrm{A}_{\mathrm{sec}}} \cdot \mathrm{PM}_{\mathrm{sec}}{ }^{1-\sigma \mathrm{A}_{\mathrm{sec}}}+\left(1-\gamma \mathrm{A}_{\mathrm{sec}}\right)^{\sigma \mathrm{A}_{\mathrm{sec}}} \cdot \mathrm{PDD}_{\mathrm{sec}}{ }^{1-\sigma \mathrm{A}_{\mathrm{sec}}}\right)^{\frac{\sigma \mathrm{A}_{\mathrm{sec}}}{1-\sigma \mathrm{A}_{\mathrm{sec}}}}
\end{aligned}
$$

1.6.4 Zero Profit Armington

$$
\mathrm{P}_{\mathrm{sec}} \cdot \mathrm{X}_{\mathrm{sec}}=\mathrm{PM}_{\mathrm{sec}} \cdot \mathrm{M}_{\mathrm{sec}}+\mathrm{PDD}_{\mathrm{sec}} \cdot \mathrm{XDD}_{\mathrm{sec}}
$$

1.6.5 Import and Export Prices

$$
\begin{gathered}
\mathrm{PM}_{\mathrm{sec}}=\left(1+\mathrm{tm}_{\mathrm{sec}}\right) \cdot \mathrm{ER} \cdot \overline{\mathrm{PWMZ}}_{\mathrm{sec}} \\
\mathrm{PE}_{\mathrm{sec}}=\mathrm{ER} \cdot \overline{\mathrm{PWEZ}}_{\mathrm{sec}}
\end{gathered}
$$

\subsection{Market Clearing}

$$
\begin{gathered}
\sum_{\text {cro }} \mathrm{LANR}_{\text {lad,cro }}=\overline{\mathrm{LANS}}_{\text {lad }} \\
\sum_{\text {agc }} \mathrm{L}_{-} \mathrm{RA}_{\text {laa,agc }}=\overline{\mathrm{LARS}}_{\text {laa }} \\
\sum_{\text {sec }} \mathrm{LNA}_{\text {sec }}=\overline{\mathrm{LNAS}} \\
\sum_{\text {sec }} \mathrm{K}=\sum_{\text {hou }} \overline{\mathrm{KH}}_{\text {hou }}+\overline{\mathrm{EK}}+\overline{\mathrm{FK}}
\end{gathered}
$$

$\sum_{\text {hou }} \mathrm{C}_{\mathrm{agch}, \mathrm{hou}}+\mathrm{I}_{\mathrm{agc}}+\mathrm{CG}_{\mathrm{agc}}+\overline{\mathrm{STC}}_{\mathrm{agc}}+\sum_{\mathrm{agcc}} \mathrm{io}_{\mathrm{agc}, \mathrm{agcc}} \cdot \mathrm{XD}_{\mathrm{agcc}}+\sum_{\mathrm{foe}} \mathrm{io}_{\mathrm{agc}, \mathrm{foe}} \cdot \mathrm{XD}_{\mathrm{foe}}+\sum_{\mathrm{wts}} \mathrm{io}_{\mathrm{agc}, \mathrm{wts}} \cdot$

$$
\mathrm{XD}_{\mathrm{wts}}=\mathrm{X}_{\mathrm{agc}}
$$

$$
\sum_{\text {hou }} \mathrm{C}_{\text {foo, hou }}+\mathrm{I}_{\text {foo }}+\mathrm{CG}_{\text {foo }}+\overline{\mathrm{STC}}_{\text {foo }}+\sum_{\mathrm{agc}} \mathrm{io}_{\text {foo,agc }} \cdot \mathrm{XD}_{\mathrm{agc}}+\sum_{\text {foe }} \mathrm{io}_{\text {foo,foe }} \cdot \mathrm{XD}_{\text {foe }}+\sum_{\mathrm{wts}} \mathrm{io}_{\text {foo,wts }} \cdot \mathrm{XD}_{\mathrm{wts}}=
$$

$$
\mathrm{X}_{\text {foo }}
$$

$$
\begin{gathered}
\sum_{\text {hou }} \mathrm{C}_{\mathrm{COA}, \mathrm{hou}}+\mathrm{I}_{\mathrm{COA}}+\mathrm{CG}_{\mathrm{COA}}+\overline{\mathrm{STC}}_{\mathrm{COA}}+\sum_{\mathrm{agc}} \mathrm{io}_{\mathrm{COA}, \mathrm{agc}} \cdot \mathrm{XD}_{\mathrm{agc}}+\sum_{\mathrm{foe}} \mathrm{COA}_{\mathrm{foe}}+\sum_{\mathrm{wts}} \mathrm{io}_{\mathrm{COA}, \mathrm{wts}} \cdot \mathrm{XD}_{\mathrm{wts}}= \\
(71)
\end{gathered}
$$

$$
\sum_{\text {hou }} \mathrm{C}_{\mathrm{PET} \text {,hou }}+\mathrm{I}_{\mathrm{PET}}+\mathrm{CG}_{\mathrm{PET}}+\overline{\mathrm{STC}}_{\mathrm{PET}}+\sum_{\mathrm{agc}} \mathrm{io}_{\mathrm{PET}, \mathrm{agc}} \cdot \mathrm{XD}_{\mathrm{agc}}+\sum_{\mathrm{foe}} \mathrm{PET}_{\mathrm{foe}}+\sum_{\mathrm{wts}} \mathrm{io}_{\mathrm{PET}, \mathrm{wts}} \cdot \mathrm{XD}_{\mathrm{wts}}=
$$$$
\mathrm{X}_{\mathrm{PET}}
$$

$$
\begin{aligned}
& \sum_{\text {hou }} \mathrm{C}_{\mathrm{GAO}, \text { hou }}+\mathrm{I}_{\mathrm{GAO}}+\mathrm{CG}_{\mathrm{GAO}}+\overline{\mathrm{STC}}_{\mathrm{GAO}}+\sum_{\mathrm{agc}} \mathrm{io}_{\mathrm{GAO}, \mathrm{agc}} \cdot \mathrm{XD}_{\mathrm{agc}}+\sum_{\mathrm{foe}} \mathrm{GAO}_{\text {foe }}+\sum_{\mathrm{wts}} \mathrm{io}_{\mathrm{GAO}, \mathrm{wts}} \cdot \mathrm{XD}_{\mathrm{wts}}= \\
& \mathrm{X}_{\mathrm{GAO}}
\end{aligned}
$$

$$
\sum_{\text {hou }} \mathrm{C}_{\mathrm{ELG}, \mathrm{hou}}+\mathrm{I}_{\mathrm{ELG}}+\mathrm{CG}_{\mathrm{ELG}}+\overline{\mathrm{STC}}_{\mathrm{ELG}}+\sum_{\mathrm{agc}} \mathrm{io}_{\mathrm{ELG}, \mathrm{agc}} \cdot \mathrm{XD}_{\mathrm{agc}}+\sum_{\mathrm{foe}} \mathrm{ELG}_{\mathrm{foe}}+\sum_{\mathrm{wts}} \mathrm{io}_{\mathrm{ELG}, \mathrm{wts}} \cdot \mathrm{XD}_{\mathrm{wts}}=
$$

$$
\mathrm{X}_{\mathrm{ELG}}
$$

$$
\sum_{\text {hou }} \mathrm{C}_{\text {ots,hou }}+\mathrm{I}_{\text {ots }}+\mathrm{CG}_{\text {ots }}+\overline{\mathrm{STC}}_{\text {ots }}+\sum_{\text {agc }} \mathrm{io}_{\text {ots,agc }} \cdot \mathrm{XD}_{\text {agc }}+\sum_{\text {foe }} \mathrm{io}_{\text {ots,foe }} \cdot \mathrm{XD}_{\text {foe }}+\sum_{\mathrm{wts}} \mathrm{io}_{\text {ots, wts }} \cdot \mathrm{XD}_{\mathrm{wts}}=
$$

$$
\mathrm{X}_{\text {ots }}
$$

$$
\sum_{\text {hou }} \mathrm{C}_{\text {was,hou }}+\mathrm{I}_{\text {was }}+\mathrm{CG}_{\text {was }}+\overline{\mathrm{GAW}}_{\text {was }}+\sum_{\text {cro }} \mathrm{WAT}_{\text {was,cro }}+\sum_{\text {ncro }} \mathrm{io}_{\text {was,ncro }} \cdot \mathrm{XD}_{\text {ncro }}+\sum_{\text {foe }} \mathrm{io}_{\text {was,foe }} \cdot
$$$$
\mathrm{XD}_{\text {foe }}+\sum_{\mathrm{wts}} \mathrm{io}_{\mathrm{was}, \mathrm{wts}} \cdot \mathrm{XD}_{\mathrm{wts}}=\mathrm{X}_{\mathrm{was}}
$$

$\sum_{\mathrm{sec}} \mathrm{M}_{\mathrm{sec}} \cdot \overline{\mathrm{PWMZ}}_{\mathrm{sec}}+\left(\frac{\mathrm{PK}}{\mathrm{ER}}\right) \cdot \overline{\mathrm{FK}}=\sum_{\mathrm{sec}} \mathrm{E}_{\mathrm{sec}} \cdot \overline{\mathrm{PWEZ}}_{\mathrm{sec}}+\sum_{\mathrm{hou}}\left(\frac{\mathrm{PCINDEX}}{\mathrm{ER}}\right) \cdot \overline{\mathrm{FH}}_{\mathrm{hou}}+\left(\frac{\mathrm{PCINDEX}}{\mathrm{ER}}\right) \cdot \overline{\mathrm{FG}}+\overline{\mathrm{SF}}$

$$
\operatorname{PCINDEX}=\frac{\sum_{\text {sec,hou }} \mathrm{P}_{\mathrm{sec}} \cdot \mathrm{C}_{\mathrm{sec}}^{0}}{\sum_{\mathrm{sec}, \mathrm{hou}} \mathrm{P}_{\mathrm{sec}}^{0} \cdot \mathrm{C}_{\mathrm{sec}}^{0}}
$$

\subsection{Real GDP and Nominal GDP}

$\mathrm{NGDP}=\mathrm{PK} \cdot \sum_{\text {sec }} \mathrm{K}_{\text {sec }}+\sum_{\text {laa }} \mathrm{PL}_{-} \mathrm{RA}_{\text {laa }} \cdot \mathrm{L}_{-} \mathrm{RA}_{\text {laa, agc }}+\overline{\mathrm{PLNA}} \cdot \sum_{\text {sec }} \mathrm{LNA}_{\text {sec }}+\sum_{\text {lad,cro }} \mathrm{PLAN}_{\text {lad }} \cdot \mathrm{LANR}_{\text {lad,cro }}+$ $\sum_{\text {sec }} \mathrm{tp}_{\mathrm{sec}} \cdot \mathrm{PD}_{\mathrm{sec}} \cdot \mathrm{XD}_{\mathrm{sec}}+\sum_{\mathrm{sec}} \mathrm{tm}_{\mathrm{sec}} \cdot \mathrm{M}_{\mathrm{sec}} \cdot \overline{\mathrm{PWMZ}}_{\mathrm{sec}} \cdot \mathrm{ER}$ 


$$
\begin{gathered}
\mathrm{RGDP}= \\
\mathrm{PK}^{0} \cdot \sum_{\text {sec }} \mathrm{K}_{\text {sec }}+\sum_{\text {laa }} \mathrm{PL}_{-} \mathrm{RA}_{\text {laa }}^{0} \cdot \mathrm{L}_{-} \mathrm{RA} A_{\text {laa, agc }}+\overline{\mathrm{PLNA}} \cdot \sum_{\text {sec }} \mathrm{LNA}_{\text {sec }}+\sum_{\text {lad,cro }} \mathrm{PLAN}_{\text {lad }}^{0} \cdot \mathrm{LANR}_{\text {lad,cro }}+ \\
\sum_{\text {sec }} \mathrm{tp}_{\text {sec }} \cdot \mathrm{PD}_{\text {sec }}^{0} \cdot \mathrm{XD}_{\text {sec }}+\sum_{\text {sec }} \mathrm{tm}_{\text {sec }} \cdot \mathrm{M}_{\text {sec }} \cdot \overline{\mathrm{PWMZ}_{\text {sec }} \cdot \mathrm{ER}^{0}}
\end{gathered}
$$

\section{Notation for Sectors}

$\begin{array}{ll}\text { sec,secc } & \text { activities and commodities } \\ \text { agc,agcc } & \text { agriculture and construction sectors } \\ \text { cro,croo } & \text { crop sectors } \\ \text { ncro,ncroo } & \text { non crop sectors including construction } \\ \text { foe,foee } & \text { food and energy sectors } \\ \text { foo,fooo } & \text { food sectors } \\ \text { en,enn } & \text { energy sectors } \\ \text { wst,wstt } & \text { water and other sectors } \\ \text { was,wass } & \text { water sectors } \\ \text { nwas,nwass } & \text { non-water sectors } \\ \text { ots,otss } & \text { other sectors } \\ \text { hou,houu } & \text { urban and 16 regional rural households } \\ \text { hour } & \text { 16 regional rural households } \\ \text { laa } & \text { agricultural labor sectors } \\ \text { lad } & \text { cropland sectors } \\ 0 & \text { Initial value in benchmark equilibrium }\end{array}$

\section{Variables}

PLNA

PK

ER

PCINDEX

PLAWA $_{\text {cro }}$

PLAWAR $_{\text {was,cro }}$

$P L_{\text {agc }}$

PL_A $A_{\text {agc }}$

$S$

SG

SE

FG

YE

EK

TRE $_{\text {hou }}$

SF

FK

LNAS

$\mathrm{P}_{\mathrm{sec}}$

$\mathrm{PD}_{\text {sec }}$

$\mathrm{PDD}_{\text {sec }}$

$\mathrm{PM}_{\text {sec }}$

$\mathrm{PE}_{\text {sec }}$

$P L_{-} R A_{\text {laa }}$

PLAN $_{\text {lad }}$ wage rate of non-agricultural labor (numeraire price index, fixed)

return to capital

exchange rate (LCU against FCU)

consumer price index (commodities)

price level of total composite land-water

price level of regional composite land and water

price level of composite labor

price level of composite agricultural labor

total savings

government savings

enterprise savings

government revenue from foreign (exogenous)

income level of enterprise

enterprise capital endowment(exogenous)

transfer for enterprise to households (exogenous)

foreign savings (exogenous)

foreign capital demand in local current (exogenous)

total non-agricultural labor supply

price level of domestic sales of composite commodities

price level of domestic output of firm

price of domestic output delivered to home market

import price EX tariffs in local currency

price of exports in local currency

wage rate of regional agricultural labor

return to regional croplands 


\begin{tabular}{|c|c|}
\hline $\mathrm{PNOE}_{\text {foe }}$ & price level of composite non-electricity input \\
\hline$P_{E N G}$ foe & price level of composite energy \\
\hline $\mathrm{PKE}_{\text {sec }}$ & price level of composite capital-energy \\
\hline PKLW $_{\text {cro }}$ & price level of composite capital-energy-land-water bundle \\
\hline $\mathrm{PKLE}_{\mathrm{sec}}$ & price level of composite capital-energy-labor bundle \\
\hline PNOCA $_{\text {foe }}$ & price level of composite non-coal \\
\hline$X_{\text {sec }}$ & domestic sales of composite commodity \\
\hline $\mathrm{XD}_{\mathrm{sec}}$ & gross domestic production (output) level firm \\
\hline $\mathrm{XDD}_{\mathrm{sec}}$ & domestic production delivered to home markets \\
\hline $\mathrm{E}_{\mathrm{sec}}$ & export demand \\
\hline $\mathrm{M}_{\mathrm{sec}}$ & import demand \\
\hline LAWAR $_{\text {was,cro }}$ & demand of regional composite land and water \\
\hline LAWA $_{\text {cro }}$ & demand of total composite land-water \\
\hline $\mathrm{LANR}_{\text {lad,cro }}$ & demand of regional croplands \\
\hline $\mathrm{LANS}_{\text {lad }}$ & total supply of regional croplands \\
\hline $\mathrm{NOE}_{\text {foe }}$ & demand for non-electricity input(composite) \\
\hline $\mathrm{ENG}_{\mathrm{foe}}$ & demand for composite energy input \\
\hline $\mathrm{KE}_{\mathrm{sec}}$ & demand for capital-energy bundle by firms \\
\hline $\mathrm{KLW}_{\text {cro }}$ & demand for capital-land-water bundle by firms \\
\hline $\mathrm{KLE}_{\text {sec }}$ & demand for capital-energy-labor bundle by firms \\
\hline $\mathrm{NOCA}_{\text {foe }}$ & demand for composite non-coal input \\
\hline $\mathrm{L}_{\mathrm{agc}}$ & demand for composite labor \\
\hline$L_{-} A_{a g c}$ & demand for composite agricultural labor \\
\hline $\mathrm{L}_{-} \mathrm{RA}_{\text {laa,agc }}$ & demand for regional agricultural labor \\
\hline $\mathrm{LNA}_{\mathrm{sec}}$ & demand for non-agricultural labor \\
\hline LARS $_{\text {laa }}$ & supply of agricultural labor in different regions \\
\hline $\mathrm{K}_{\mathrm{sec}}$ & capital demand of firms \\
\hline $\mathrm{COA}_{\text {foe }}$ & demand for coal of firms \\
\hline $\mathrm{PET}_{\text {foe }}$ & demand for petroleum products \\
\hline $\mathrm{GAO}_{\text {foe }}$ & demand for gasoline \\
\hline $\mathrm{ELG}_{\mathrm{sec}}$ & demand for electricity and gas \\
\hline WAT $_{\text {was,cro }}$ & demand for regional water of each crop \\
\hline $\mathrm{GAW}_{\text {was }}$ & water gap between water demand and supply (exogenous) \\
\hline $\mathrm{C}_{\text {sec,hou }}$ & consumer demand for commodities and leisure \\
\hline CBUD $_{\text {hou }}$ & total consumption \\
\hline $\mathrm{SH}_{\text {hou }}$ & households' savings \\
\hline $\mathrm{KH}_{\text {hou }}$ & initial households' capital holding (exogenous) \\
\hline $\mathrm{FH}_{\text {hou }}$ & initial households' foreign revenues (exogenous) \\
\hline$Y_{\text {hou }}$ & initial households' income level \\
\hline $\mathrm{I}_{\mathrm{sec}}$ & investment demand \\
\hline $\mathrm{CG}_{\mathrm{sec}}$ & government commodity demand \\
\hline TAXR & total tax revenue of government \\
\hline $\mathrm{TRF}_{\text {hou }}$ & transfer from government to household (exogenous) \\
\hline NGDP & nominal gross domestic products of macro economy \\
\hline RGDP & real gross domestic products of macro economy \\
\hline PLES $_{\text {hou }}$ & aggregate price level for the "proposed change" \\
\hline PLES_10 hou & index of aggregate price level \\
\hline $\mathrm{SI}_{\text {hou }}$ & supernumerary income for the "proposed change" \\
\hline
\end{tabular}




$\begin{array}{ll}\mathrm{EV}_{\text {hou }} & \text { equivalent variation of policy scenario } \\ \mathrm{CV}_{\mathrm{hou}} & \text { compensating variation of policy scenario } \\ \mathrm{PK}^{0} & \text { Initial return to capital } \\ \mathrm{P}_{\text {sec }}^{0} & \text { initial price level of domestic sales of composite commodities } \\ \mathrm{PD}_{\text {sec }}^{0} & \text { initial price level of domestic output of firm } \\ \mathrm{C}_{\text {sec }}^{0} & \text { initial price level of domestic sales of composite commodities } \\ \mathrm{PL}_{-} \mathrm{RA}_{\text {laa }}^{0} & \text { initial wage rate of regional agricultural labor } \\ \mathrm{PLAN}_{\text {lad }}^{0} & \text { Initial return to regional croplands } \\ \mathrm{PWEZ}_{\text {sec }} & \text { initial world price of experts (exogenous) } \\ \mathrm{PWMZ}_{\text {sec }} & \text { initial world price of imports (exogenous) } \\ \mathrm{ER}^{0} & \text { initial exchange rate (LCU against FCU) } \\ \mathrm{PLES}_{\text {sec }}^{0} & \text { initial aggregate price level for the "proposed change" } \\ \mathrm{SI}_{\text {sec }}^{0} & \text { initial supernumerary income for the "proposed change" }\end{array}$

\section{Parameters}

\begin{tabular}{|c|c|}
\hline$\sigma L W_{\text {cro }}$ & elasticity of substitution between cropland and water \\
\hline$\sigma \mathrm{NOE}_{\mathrm{sec}}$ & elasticity of substitution between non-electricity \\
\hline$\sigma \mathrm{KLW}_{\text {cro }}$ & elasticity of substitution between KE and LAWA \\
\hline$\sigma \mathrm{KE}_{\mathrm{sec}}$ & elasticity of substitution between capital and energy \\
\hline$\sigma \mathrm{LB}_{\mathrm{agc}}$ & elasticity of substitution between agricultural labor and non-agricultural labor \\
\hline$\sigma \mathrm{KLE}_{\text {sec }}$ & elasticity of substitution between capital-energy and labor \\
\hline$\sigma \mathrm{VA}_{\mathrm{wts}}$ & elasticity of substitution between capital and labor \\
\hline$\sigma \mathrm{A}_{\mathrm{sec}}$ & substitution elasticity of ARMINGTON function \\
\hline$\sigma \mathrm{T}_{\mathrm{sec}}$ & substitution elasticity of CET function \\
\hline$\gamma \mathrm{LW}_{\text {was,sec }}$ & CES distribution parameter for cropland and water bundle \\
\hline$\gamma \mathrm{NOE}_{\mathrm{sec}}$ & CES distribution parameter for non-electricity bundle \\
\hline$\gamma \mathrm{KLW}_{\text {cro }}$ & CES distribution parameter for capital-land-water bundle \\
\hline$\gamma \mathrm{KE}_{\mathrm{sec}}$ & CES distribution parameter for capital-energy bundle \\
\hline$\gamma \mathrm{LB}_{\mathrm{sec}}$ & CES distribution parameter for composite labor \\
\hline$\gamma \mathrm{KLE}_{\mathrm{sec}}$ & CES distribution parameter for capital-energy-labor bundle \\
\hline$\gamma \mathrm{VA}_{\mathrm{wts}}$ & CES distribution parameter for value added in other sectors \\
\hline$\gamma \mathrm{A}_{\mathrm{sec}}$ & CES distribution parameter for Armington function \\
\hline$\gamma \mathrm{T}_{\mathrm{sec}}$ & CES distribution parameter for CET function \\
\hline$\alpha \mathrm{NOE}_{\text {sec }}$ & Cobb-Douglas power of NOE in non-electricity bundle \\
\hline$\alpha \mathrm{ELG}_{\mathrm{sec}}$ & Cobb-Douglas power of ELG in non-electricity bundle \\
\hline$\alpha \mathrm{LW}_{\text {was,cro }}$ & Cobb-Douglas power of regional composite land-water bundle \\
\hline$\alpha \mathrm{LB}_{\text {laa,agc }}$ & Cobb-Douglas power of regional agricultural labor \\
\hline$\alpha \mathrm{L}_{\mathrm{agc}}$ & Cobb-Douglas power of composite labor in value added bundle \\
\hline$\alpha K_{\text {ncro }}$ & Cobb-Douglas power of Capital in value added bundle \\
\hline$\alpha \mathrm{KE}_{\mathrm{agc}}$ & Cobb-Douglas power of composite energy-capital bundle \\
\hline$\alpha \mathrm{KLW}_{\text {cro }}$ & Cobb-Douglas power of composite capital \\
\hline$\alpha \mathrm{PET}_{\text {foe }}$ & Cobb-Douglas power of PET in non-coal bundle \\
\hline$\alpha \mathrm{GAO}_{\text {foe }}$ & Cobb-Douglas power of GAO in non-coal bundle \\
\hline$\alpha \mathrm{NOCA}_{\text {foe }}$ & efficiency parameter for non-coal bundle \\
\hline $\mathrm{aNOE}_{\mathrm{sec}}$ & efficiency parameter for non-electricity bundle \\
\hline $\mathrm{aENG}_{\text {sec }}$ & efficiency parameter for energy bundle \\
\hline $\mathrm{aKE}_{\mathrm{sec}}$ & efficiency parameter for capital-energy bundle \\
\hline $\mathrm{aKLW}_{\text {cro }}$ & efficiency parameter for composite capital \\
\hline $\mathrm{aLW}_{\text {cro }}$ & efficiency parameter for composite land-water bundle \\
\hline
\end{tabular}




$\begin{array}{ll}\mathrm{aRLW}_{\text {was,cro }} & \text { efficiency parameter for regional composite land-water bundle } \\ \mathrm{aRLB}_{\text {agc }} & \text { efficiency parameter for regional agricultural labor } \\ \alpha \mathrm{LB}_{\mathrm{agc}} & \text { efficiency parameter for composite labor } \\ \mathrm{aKLE}_{\text {sec }} & \text { efficiency parameter for capital-energy-labor bundle } \\ \mathrm{aVA}_{\text {sec }} & \text { efficiency parameter for value added } \\ \mathrm{aA}_{\text {sec }} & \text { efficiency parameter of ARMINGTON function of commodity(sec) } \\ \mathrm{aT}_{\text {sec }} & \text { shift parameter in the CET function of firm (sec) } \\ \mathrm{io}_{\text {sec,secc }} & \text { technical coefficients } \\ \alpha \mathrm{HLES}_{\text {sec,hou }} & \text { power in nested-ELES household utility function } \\ \mu \mathrm{H}_{\text {sechou }} & \text { subsistence household consumption quantities(sec) } \\ \mathrm{mps}_{\text {hou }} & \text { household's marginal propensity to save } \\ \mathrm{mpe} & \text { enterprise's marginal propensity to save } \\ \mathrm{mpg}_{\text {mpg }} & \text { government's marginal propensity to save } \\ \text { tye } & \text { tax rate on enterprise' income } \\ \text { ty } & \text { tax rate on households' income } \\ \mathrm{tm}_{\text {sec }} & \text { tariff rate for each sector } \\ \alpha \mathrm{I}_{\text {sec }} & \text { Cobb-Douglas power in the bank's utility function } \\ \mathrm{tp}_{\text {sec }} & \text { net production tax } \\ \alpha \mathrm{CG} & \text { Cobb-Douglas power in government utility function (commodities) }\end{array}$

Appendix 2. Values of given parameters using in CGE-Energy model

\begin{tabular}{|c|c|c|c|c|c|c|c|c|}
\hline & & Abbreviations & $\begin{array}{l}\text { Tariff } \\
\text { rate } \\
(\%)^{*}\end{array}$ & $\begin{array}{c}\text { Armington } \\
\text { elasticity* } \\
\quad *\end{array}$ & $\begin{array}{c}\text { CET } \\
\text { Elasticity } \\
* *\end{array}$ & $\begin{array}{c}\text { Income } \\
\text { Elasticity of } \\
\text { Commodities } \\
* * *\end{array}$ & $\begin{array}{c}\sigma_{V A} \\
* * * *\end{array}$ & $\sigma_{* * * *}$ \\
\hline \multirow{14}{*}{ 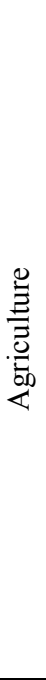 } & Paddy & PDR & 0.081 & 5.1 & 3.6 & 0.23 & 1 & \\
\hline & Wheat & WHT & 0.081 & 4.5 & 3.6 & 0.23 & 1 & \\
\hline & Corn & $\mathrm{COR}$ & 0.081 & 1.3 & 3.6 & 0.23 & 1 & \\
\hline & Vegetables & VEG & 0.032 & 2.5 & 3.6 & 0.23 & 1 & \\
\hline & Fruits & FRU & 0.037 & 2.5 & 3.6 & 0.23 & 1 & \\
\hline & Oil seeds & OSD & 0.032 & 2.5 & 3.6 & 0.23 & 1 & \\
\hline & Sugarcane & SUR & 0.077 & 2.5 & 3.6 & 0.23 & 1 & \\
\hline & Potato & POT & 0.02 & 2.5 & 3.6 & 0.23 & 1 & \\
\hline & Sorghum & SOR & 0.005 & 2.5 & 3.6 & 0.23 & 1 & \\
\hline & other crops & OCR & 0.033 & 2.5 & 3.6 & 0.23 & 1 & \\
\hline & Livestock & LIS & 0.033 & 1.5 & 3.6 & 0.23 & 1 & \\
\hline & Forestry & FOS & 0.028 & 2.5 & 3.6 & 0.23 & 1 & \\
\hline & Fishery & FIS & 0.029 & 1.3 & 3.6 & 0.23 & 1 & \\
\hline & $\begin{array}{l}\text { Service for } \\
\text { Agricultural }\end{array}$ & SSA & 0 & 2.5 & 3.6 & 0.23 & 1 & \\
\hline \multirow{4}{*}{ 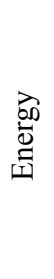 } & Coal & $\mathrm{COA}$ & 0.011 & 3.1 & 4.6 & 1.23 & & 0.2 \\
\hline & $\begin{array}{l}\text { Petroleum } \\
\text { products: Oil and } \\
\text { Gas Exploitation }\end{array}$ & PET & 0.016 & 7.4 & 4.6 & 1.23 & & 0.2 \\
\hline & $\begin{array}{l}\text { Gasoline and Other } \\
\text { Oil Products }\end{array}$ & GAO & 0.009 & 2.1 & 3.8 & 1.12 & & 1.26 \\
\hline & $\begin{array}{l}\text { Electricity and } \\
\text { GAS }\end{array}$ & ELG & 0 & 2.8 & 3.8 & 1.23 & & 1.26 \\
\hline
\end{tabular}


Appendix 2. Values of given parameters using in CGE-Energy model (continued)

\begin{tabular}{|c|c|c|c|c|c|c|c|c|}
\hline & & Abbreviations & $\begin{array}{l}\text { Tariff } \\
\text { rate } \\
(\%)^{*}\end{array}$ & $\begin{array}{c}\text { Armington } \\
\text { elasticity* } \\
*\end{array}$ & $\begin{array}{c}\text { CET } \\
\text { Elasticity } \\
* *\end{array}$ & $\begin{array}{c}\text { Income } \\
\text { Elasticity of } \\
\text { Commodities } \\
* * *\end{array}$ & $\begin{array}{c}\sigma_{V A} \\
* * * *\end{array}$ & $\begin{array}{l}\sigma_{K L E} \\
* * * *\end{array}$ \\
\hline \multirow{7}{*}{$\begin{array}{l}\overrightarrow{8} \\
8 \\
\end{array}$} & Meat Processing & MEP & 0.047 & 2.6 & 4.5 & 0.8 & & 1.45 \\
\hline & $\begin{array}{l}\text { Vegetable Oils } \\
\text { Processing }\end{array}$ & VOL & 0.027 & 3.3 & 4.5 & 0.8 & & 1.45 \\
\hline & Milk Processing & MIL & 0.024 & 2.6 & 4.5 & 0.8 & & 1.45 \\
\hline & $\begin{array}{l}\text { Grain and Feed } \\
\text { Processing }\end{array}$ & GOG & 0.027 & 2.6 & 4.5 & 0.8 & & 1.45 \\
\hline & Sugar Processing & SUG & 0.064 & 2.7 & 4.7 & 0.8 & & 1.45 \\
\hline & $\begin{array}{l}\text { Other Food } \\
\text { Processing }\end{array}$ & OTF & 0.035 & 2.2 & 4.5 & 0.8 & & 1.45 \\
\hline & $\begin{array}{l}\text { Alcohol, Drinks } \\
\text { and Tobacco } \\
\text { production }\end{array}$ & ADT & 0.082 & 1.2 & 4.7 & 0.8 & & 1.45 \\
\hline \multirow{8}{*}{$\frac{\tilde{\omega}}{\tilde{\Xi}}$} & Other Mining & $\mathrm{OMN}$ & 0.003 & 2.8 & 4.6 & 0.8 & 1.45 & \\
\hline & Other Manufactures & OTM & 0.023 & 2.8 & 4.6 & 1.01 & 1.45 & \\
\hline & Construction & $\mathrm{CNS}$ & 0 & 1.9 & 3.8 & 1.23 & 1 & \\
\hline & Trade & TRD & 0 & 1.9 & 2.8 & 1.29 & 1.45 & \\
\hline & Transportation & TRS & 0 & 1.9 & 2.8 & 1.29 & 1.45 & \\
\hline & $\begin{array}{l}\text { Insurance and } \\
\text { Finance }\end{array}$ & $\mathrm{I} \& \mathrm{~F}$ & 0 & 1.9 & 2.8 & 1.29 & 1.28 & \\
\hline & $\begin{array}{l}\text { Communication } \\
\text { and Computer }\end{array}$ & $\mathrm{CMC}$ & 0 & 1.9 & 2.8 & 1.29 & 1.28 & \\
\hline & Other Service & OTS & 0 & 1.9 & 2.8 & 1.29 & 1.28 & \\
\hline \multirow{16}{*}{ 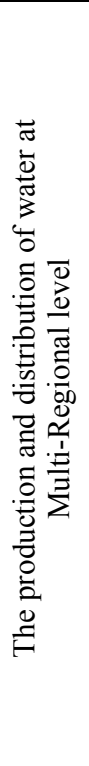 } & Water-Guangdong & WAT-GD & 0 & 2.8 & 2.8 & 1.23 & 1.28 & \\
\hline & Water-Jiangxi & WAT-JX & 0 & 2.8 & 2.8 & 1.23 & 1.28 & \\
\hline & Water-Hainan & WAT-HN & 0 & 2.8 & 2.8 & 1.23 & 1.28 & \\
\hline & Water-Yunnan & WAT-YN & 0 & 2.8 & 2.8 & 1.23 & 1.28 & \\
\hline & Water-Guangxi & WAT-GX & 0 & 2.8 & 2.8 & 1.23 & 1.28 & \\
\hline & Water-Henan & WAT-HEN & 0 & 2.8 & 2.8 & 1.23 & 1.28 & \\
\hline & Water-Jilin & WAT-JL & 0 & 2.8 & 2.8 & 1.23 & 1.28 & \\
\hline & Water-Anhui & WAT-AH & 0 & 2.8 & 2.8 & 1.23 & 1.28 & \\
\hline & Water-Heilongjiang & WAT-HLJ & 0 & 2.8 & 2.8 & 1.23 & 1.28 & \\
\hline & Water-Hebei & WAT-HB & 0 & 2.8 & 2.8 & 1.23 & 1.28 & \\
\hline & Water-Hubei & WAT-HUB & 0 & 2.8 & 2.8 & 1.23 & 1.28 & \\
\hline & Water-Chongqing & WAT-CQ & 0 & 2.8 & 2.8 & 1.23 & 1.28 & \\
\hline & Water-Sichuan & WAT-SC & 0 & 2.8 & 2.8 & 1.23 & 1.28 & \\
\hline & $\begin{array}{l}\text { Water-Inner } \\
\text { Mongolia }\end{array}$ & WAT-NMG & 0 & 2.8 & 2.8 & 1.23 & 1.28 & \\
\hline & Water-Shandong & WAT-SD & 0 & 2.8 & 2.8 & 1.23 & 1.28 & \\
\hline & Water-other regions & WAT-OTH & 0 & 2.8 & 2.8 & 1.23 & 1.28 & \\
\hline
\end{tabular}

Source: Ge and Tokunaga (2011)*; Zhai and Hertel (2005)**; Willenbockel (2006)***; Burniaux and Truong (2002)****.

\section{Copyrights}

Copyright for this article is retained by the author(s), with first publication rights granted to the journal.

This is an open-access article distributed under the terms and conditions of the Creative Commons Attribution license (http://creativecommons.org/licenses/by/3.0/). 